Review

\title{
Applications of Nanosized-Lipid-Based Drug Delivery Systems in Wound Care
}

\author{
Andreea-Mariana Matei ${ }^{1,2}$, Constantin Caruntu $1,3, * \mathbb{D}$, Mircea Tampa ${ }^{4,5, * \mathbb{D}}$, Simona Roxana Georgescu ${ }^{4,5} \mathbb{D}_{\text {, }}$ \\ Clara Matei ${ }^{2,4}$, Maria Magdalena Constantin 2,4 , Traian Vasile Constantin 6,7, Daniela Calina ${ }^{8(D)}$, \\ Diana Alina Ciubotaru ${ }^{1,9}$, Ioana Anca Badarau ${ }^{1}$, Cristian Scheau ${ }^{1}$ (D) and Ana Caruntu ${ }^{9,10}$ (D)
}

1 Department of Physiology, “Carol Davila" University of Medicine and Pharmacy, 050474 Bucharest, Romania; andreea.matei@drd.umfcd.ro (A.-M.M.); diana-alina.ciubotaru@drd.umfcd.ro (D.A.C.); anca.badarau@umfcd.ro (I.A.B.); cristian.scheau@umfcd.ro (C.S.)

2 Colentina Clinical Hospital, 020125 Bucharest, Romania; matei_clara@yahoo.com (C.M.); drmagdadinu@yahoo.com (M.M.C.)

3 Department of Dermatology, "Prof. N.C. Paulescu" National Institute of Diabetes, Nutrition and Metabolic Diseases, 011233 Bucharest, Romania

4 Department of Dermatology, "Carol Davila" University of Medicine and Pharmacy, 020021 Bucharest, Romania; simonaroxanageorgescu@yahoo.com

5 Department of Dermatology, "Victor Babes" Clinical Hospital for Infectious Diseases, 030303 Bucharest, Romania

6 Department of Urology, "Carol Davila” University of Medicine and Pharmacy, 020021 Bucharest, Romania; traianc29@yahoo.com

7 "Prof. Dr. Theodor Burghele" Clinical Hospital, 050659 Bucharest, Romania

check for

updates

Citation: Matei, A.-M.; Caruntu, C.; Tampa, M.; Georgescu, S.R.; Matei, C.; Constantin, M.M.; Constantin, T.V.;

Calina, D.; Ciubotaru, D.A.; Badarau, I.A.; et al. Applications of Nanosized-Lipid-Based Drug Delivery Systems in Wound Care. Appl. Sci. 2021, 11, 4915. https:// doi.org/10.3390/app11114915

Academic Editor: Ioana Chiulan

Received: 26 April 2021

Accepted: 24 May 2021

Published: 27 May 2021

Publisher's Note: MDPI stays neutral with regard to jurisdictional claims in published maps and institutional affiliations.

Copyright: (c) 2021 by the authors. Licensee MDPI, Basel, Switzerland. This article is an open access article distributed under the terms and conditions of the Creative Commons Attribution (CC BY) license (https:/ / creativecommons.org/licenses/by/ $4.0 /)$.
8 Department of Clinical Pharmacy, University of Medicine and Pharmacy of Craiova, 200349 Craiova, Romania; calinadaniela@gmail.com

9 Department of Oral and Maxillofacial Surgery, "Carol Davila" Central Military Emergency Hospital, 010825 Bucharest, Romania; ana.caruntu@gmail.com

10 Department of Oral and Maxillofacial Surgery, Faculty of Dental Medicine, "Titu Maiorescu" University, 031593 Bucharest, Romania

* Correspondence: costin.caruntu@gmail.com (C.C.); tampa_mircea@yahoo.com (M.T.)

Abstract: Impaired wound healing is an encumbering public health issue that increases the demand for developing new therapies in order to minimize health costs and enhance treatment efficacy. Available conventional therapies are still unable to maximize their potential in penetrating the skin at the target site and accelerating the healing process. Nanotechnology exhibits an excellent opportunity to enrich currently available medical treatments, enhance standard care and manage wounds. It is a promising approach, able to address issues such as the permeability and bioavailability of drugs with reduced stability or low water solubility. This paper focuses on nanosized-lipid-based drug delivery systems, describing their numerous applications in managing skin wounds. We also highlight the relationship between the physicochemical characteristics of nanosized, lipidbased drug delivery systems and their impact on the wound-healing process. Different types of nanosized-lipid-based drug delivery systems, such as vesicular systems and lipid nanoparticles, demonstrated better applicability and enhanced skin penetration in wound healing therapy compared with conventional treatments. Moreover, an improved chemically and physically stable drug delivery system, with increased drug loading capacity and enhanced bioavailability, has been shown in drugs encapsulated in lipid nanoparticles. Their applications in wound care show potential for overcoming impediments, such as the inadequate bioavailability of active agents with low solubility. Future research in nanosized-lipid-based drug delivery systems will allow the achievement of increased bioavailability and better control of drug release, providing the clinician with more effective therapies for wound care.

Keywords: lipid-based drug delivery systems; vesicular systems; nanoparticles; nanostructured lipid carriers; solid lipid nanoparticles; wound care; impaired wound healing 


\section{Introduction}

The process of cutaneous wound healing is a sophisticated physiological event, and it is critical for restoring the integrity of the skin barrier. It involves activation of the immune system's cellular components, the coagulation cascade, and the inflammatory pathways, leading to a massive remodeling of all skin compartments [1,2]. Three sequential phases characterize the wound-healing process: the inflammatory phase, proliferative phase and the remodeling phase (maturation). The inflammatory phase arises immediately after tissue injury. The extravasation of blood constituents activates platelet adhesion, activation and aggregation. Furthermore, it leads to the formation of a fibrin clot. The next phase starts $48 \mathrm{~h}$ after the onset of the lesion. It is called the proliferative phase. When many new blood vessels are formed, several cells such as fibroblasts and endothelial cells are recruited to form new granulation tissue to cover and fill the wound area. Granulation tissue creates a three-dimensional extracellular network of connective tissue. The third phase of wound healing consists of remodeling or maturation, which lasts for several months or more and begins at 2 or 3 weeks after the onset of the lesion [3,4].

Wounds can result from the action of intrinsic factors associated with a plethora of conditions, such as diabetes, neuropathy, vascular disease and various extrinsic factors involving mechanical, chemical or thermal injuries. They can be classified into acute wounds that pass through each of the healing stages, resulting in skin restoration, and chronic wounds that exhibit a persistent inflammation phase and fail to restore the damaged skin's integrity [5]. Many factors can hamper the healing process. For instance, if a wound is contaminated with microorganisms, covered by necrotic tissue or external particles that cannot be removed during acute inflammation, the result is a chronic wound [6-10].

Despite intensive research, impaired wound healing remains a significant healthcare challenge. The investment of healthcare systems in non-healing injuries, scars from surgical incisions, trauma or burns exceeds billions each year [11-13]. For example, in the United States, almost $2 \%$ of the population are affected by chronic wounds, and the overall cost for the US health care system is estimated at USD 25 billion annually [12,14]. In Europe, 1.5-2 million people suffer from acute or chronic wounds [11]. A multicenter study covering three hospitals in Bradford and Airedale emphasized that most of the wounds were caused by surgery or trauma (48\%), leg or foot ulcers (28\%) and pressure ulcers (21\%) [15].

Patients with risk factors such as smoking, diabetes mellitus, sickle cell disease, vascular insufficiency, atherosclerotic disease, local pressure effects and immunological factors are predisposed to abnormal healing, which leads to chronic wounds $[10,16,17]$. Patients with impaired wound healing blame a diminished quality of life or psychological or financial problems, and they experience depression, social isolation and the loss of daily activities [18-21]. Aside from that, non-healing wounds are associated with prolonged hospitalization time, high morbidity and mortality [22].

Given the overwhelming pressure that impaired wound healing applies on the healthcare system, there is an increasing demand to develop new therapies in wound care to minimize health costs and enhance treatment efficacy $[11,12,23]$. The purpose of wound care is to promptly prevent complications and bypass the evolution of impaired healing. That notwithstanding, several novel approaches in wound healing treatments have failed, giving rise to an increased interest in nanotechnology advancements [24].

Nanotechnology exhibits an excellent opportunity to enrich currently available medical treatments, enhance standard care and manage wounds. It is a fascinating field with broad applications and unique properties, such as a small size, high drug incorporation capacity, large surface-area-to-volume ratio and high reactivity. Furthermore, nanotechnology allows for discovering innovative drug delivery systems, fashioned to enhance drug release control and re-establish damaged skin tissue $[25,26]$. 
Currently, a variety of drug delivery systems are feasible for wound management. However, a recent increasing trend is represented by nanosized-lipid-based drug delivery systems [27-29], which are promising tools designed to address issues such as the permeability and bioavailability of drugs with low water solubility.

This review aims to describe the current applications of nanosized-lipid-based drug delivery systems in the management of skin wounds, highlighting the relationship between their physicochemical characteristics and the impact on the wound-healing process.

\section{Nanosized-Lipid-Based Drug Delivery Systems}

Nanosized-lipid-based drug delivery systems have demonstrated substantial capabilities for dermal and transdermal drug administration. They consist of biocompatible and biodegradable lipids that accomplish controlled release, targeted delivery and drug protection. These drug delivery systems have emphasized the capacity to enclose a multitude of therapeutic agents, including growth factors, gene therapy or cytokines [30-32].

It is known that intact skin acts as a barrier against the penetration of topical formulations. Moreover, studies have reported poor permeability of drug molecules even in damaged skin [33,34], enforcing the importance of developing novel delivery systems in order to attain the specific target layer of the skin.

Among the most promising possibilities of overcoming these issues, nanosized-lipidbased drug delivery systems can provide unique properties for delivering drug molecules in the targeted areas and improve skin wound healing. They are classified as vesicular systems and lipid nanoparticles $[35,36]$ (see Figure 1). Furthermore, we emphasize their structures in Figure 2.

Vesicular systems consist of amphiphilic molecules, owing to the presence of a polar or hydrophilic region (head) and a nonpolar or lipophilic region (tail), and these can be further categorized into liposomes, ultra-deformable liposomes and ethosomes [35,37].

Regarding the properties of lipid vesicles, their sizes vary from 40 to $800 \mathrm{~nm}$, which allows them to cling to the lipid matrix of the corneous layer and increase the amount of drug molecules that penetrate the deeper skin layers. It is noteworthy that the vesicles' particle sizes influence drug delivery into the skin. The maximum delivery of molecules has been shown in vesicles with a size $\leq 70 \mathrm{~nm}[32,37,38]$.

A growing interest has been directed toward lipid nanoparticles [39] which, based on recent findings, are superior to vesicular systems, as they exhibit better penetration into the deeper layers of the epidermis [32]. Research in lipid nanoparticles has increased considerably given their advantages, especially the smaller size, deeper skin penetration and improved cost-effectiveness. Moreover, they allow the inclusion of biocompatible components approved for pharmaceutical and cosmetic use, incorporating molecules with varying solubility, increased diffusion through the skin by combination with physical and mechanical enhancers, targeted delivery and decreased systemic side effects [40].

Lipid nanoparticles are categorized into solid nanoparticles (SLNs), which can be an alternative to traditional lipid-based formulations such as liposomes and emulsions [41], and a second generation named nanostructured lipid carriers (NCLs), an improved version of SLNs [24]. The complex lipid matrix of the NCLs, including liquid lipids (oils), generates changes in the structure of the solid lipids, leading to a less ordered crystalline arrangement that averts drug leakage and supplies a higher drug load compared with SLNs, which are formed only by solid lipids and a matrix with no imperfections [42,43]. In addition, properties such as the size of the lipid nanoparticles influence their type of delivery. For instance, particles smaller than $10 \mathrm{~nm}$ can directly pass through the stratum corneum of viable human skin, while larger particles between $10 \mathrm{~nm}$ and $200 \mathrm{~nm}$ access the skin via hair follicle openings [44]. Furthermore, the composition of the physiological lipids of the lipid nanoparticles enhances the rearrangement and fluidization of the stratum corneum lipid matrix, leading to better permeability of drug molecules. Moreover, their occlusion effect can prevent water loss, leading to enhanced skin hydration $[24,45]$. 
Nanosized-Lipid-Based Drug Delivery Sytems in Wound Care
- Size range: $20 \mathrm{~nm}-5 \mu \mathrm{m}$

- Drug encapsulation efficiency: low $(30 \%)$

- Drug loading capacity: Low (15\%-20\%)

- Storage stability profile: unstable, fusion of the vesicles

- Suitable for lyophilization

- Capacity to encapsulate both hydro-soluble and liposoluble drugs

- Non-toxic, biocompatible, biodegradable

- Rapid drug leakage

- Size range: $100-400 \mathrm{~nm}$

- Drug encapsulation efficiency: high (90\%)

- Drug loading capacity: high

- Storage stability profile: unstable

- Suitable for lyophilization

- Remarkable deformability

- Higher permeability capability

- Expensive to scale-up

- Tendency to oxidative degradation

- Size range: $103-200 \mathrm{~nm}$

- Drug encapsulation efficiency: high

- Drug loading capacity: high

- Storage stability profile: susceptible to physical instability

- Suitable for lyophilization

- Higher permeability

- Low-risk profile

- Efficient skin delivery

- Poor yield

- Size range: $\mathbf{5 0 - 5 0 0 ~ n m ~}$

- Drug encapsulation efficiency: medium/high (50-100\%)

- Drug loading capacity: low (33\%)

- Storage stability profile: unstable, drug escape through matrix

- Suitable for lyophilization

- Shield active substances against degradation

- Controlled drug release

- Biodegradable and easy to sterilize

- Low local adverse reactions,

- Easy to scale up

- Propensity to gelation

- Size range: $50-300 \mathrm{~nm}$

- Drug encapsulation efficiency: high (85\%)

- Drug loading capacity: high

- Suitable for lyophilization

- Storage stability profile: stable

- Reduced risk of drug extrusion

- Enhanced bioavailability

- Easy to scale up

- Particle size growth during storage time

Figure 1. Characteristics of nanosized-lipid-based drug delivery systems applied in wound care. 
(a)

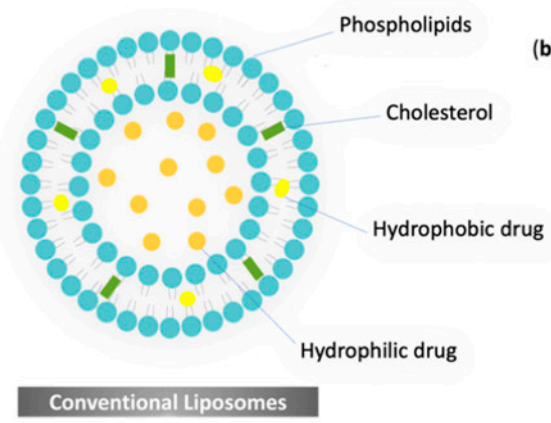

(b)
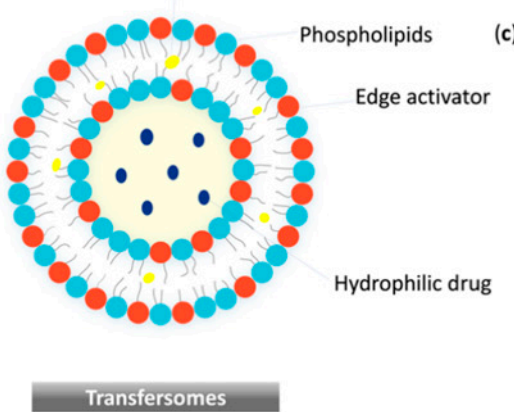

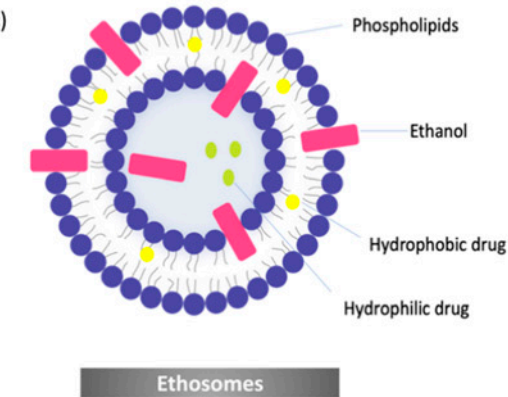

(e) (d)

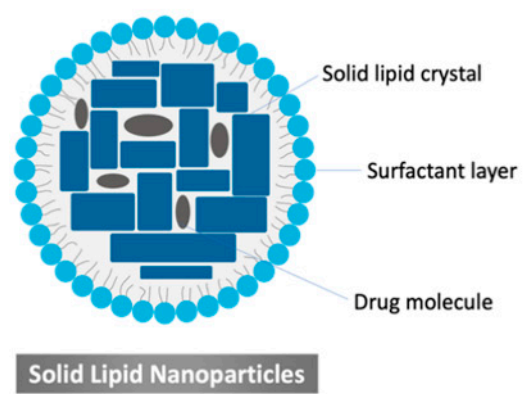

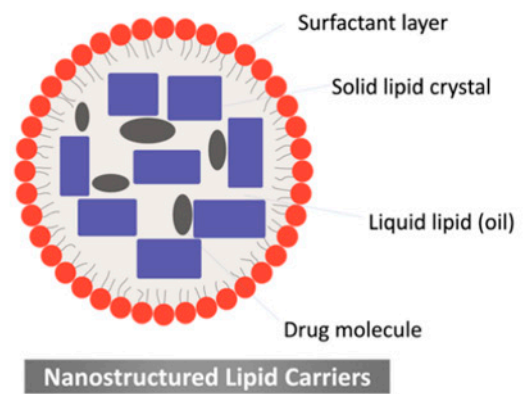

Figure 2. The structure of nanosized-lipid-based drug delivery systems applied in wound care: (a) conventional liposomes, (b) transfersomes, (c) ethosomes, (d) solid lipid nanoparticles and (e) nanostructured lipid carriers.

\section{Nanosized-Lipid-Based Drug Delivery Systems in Wound Healing}

The skin has a crucial role in maintaining body fluids homeostasis, thermoregulation and preventing microorganism penetration. Several skin wounds may present different needs in terms of treatment due to the difference in each pathophysiology. Regarding acute burn wounds, not only are the skin structures damaged, but all the systems are affected due to the leakage of plasma into interstitial spaces, which can also lead to hypovolemic shock, depending on the extension of the burn. Moreover, the affected skin barrier increases the susceptibility to bacterial infection. Therefore, in the management of burn wounds, an imperative goal is to prevent infections and enhance reepithelization in order to preserve skin functionality [46]. Most efforts have been focused on the antimicrobial activity of topical agents, which have failed in front of the increased antibiotic resistance rate [47]. Thus, a wide range of nanosized-lipid-based delivery systems such as liposomes [48-50], transfersomes [51], ethosomes and lipid nanoparticles [52] has been explored to overcome infections and enhance skin regeneration in burn wounds, with promising results.

In open wounds such as lacerations, where the underlying tissues are cut by sharpededged instruments, the imperative treatment is to clean the wound and remove any foreign bodies or dead tissue [53].

Chronic wounds are associated with an impaired repair process prolonged for more than three months [10], produced by an extended inflammation phase, persistent infections, impaired angiogenesis or a high amount of reactive oxygen species. The most common ones are non-healing ulcers caused by venous insufficiency or diabetes [54]. Current treatments in chronic wounds focus on nanoparticles containing dressings that can maintain a suitable moist environment, prevent infection and promote the wound-healing process. Progress in nanosized-lipid-based drug delivery systems has led to new treatments in chronic wounds, increasing the half-time and bioavailability of the drugs and reducing the cost, the toxicity and the number of applications [54]. Several molecules, such as all-trans retinoic acid [55], 20(S)-protopanaxadiol [56], epidermal growth factor (EGF), curcumin [57], phenytoin [58] and tumor necrosis factor $\alpha$ [59], have been encapsulated in several nanosized-lipid-based 
drug delivery systems to treat wounds associated with diabetes, with promising effects for different wound healing phases.

Lipid nanoparticles could be more suitable in burn wounds and chronic wounds due to their occlusive effect on the stratum corneum, which can avoid transepidermal water loss and keep the wound hydrated. In addition, the nanostructured lipid carriers are presented as better nano-delivery systems compared with vesicular systems. They exhibit excellent stability, low toxicity, high drug loading capacity and sustained drug release, which can help reduce the number of drug administrations and the wound's healing time [60,61].

Surgical wounds are predisposed to an increased inflammatory reaction due to suture materials, which can lead to infections, hematomas or dehiscence. These effects prolong the wound-healing process and delay hospital discharge, increasing the costs and morbidity [62]. In this case, antimicrobial advanced wound dressings are suitable to treat the wounds [63]. Additionally, nanosized-lipid-based drug delivery systems showed promising results in treating excisional wounds in rats $[52,55-57,64,65]$. Furthermore, surgical wounds may be followed by excessive collagen synthesis in the remodeling phase, leading to keloid or hypertrophic scars [66].

The skin has an essential protective function against aggressive environmental factors, but it also prevents the penetration of topical agents. The skin's primary barrier is the stratum corneum, which is formed by corneocytes and a lipid-rich matrix (chain ceramides, free fatty acids and cholesterol). It counteracts the penetration of most hydrophilic and macromolecular drugs into the skin. Given that the stratum corneum is impenetrable for most drugs, nanosized-lipid-based drug delivery systems represent a biochemical strategy to deliver both hydrophilic and hydrophobic drugs into the skin [28].

An active topical substance can penetrate the skin through three pathways: intracellular, intercellular and transfollicular pathways [67]. Liposomes penetrate the skin as an intracellular delivery system and deposit the drugs into the outer layer of the skin, providing prolonged release of the drug [68]. Moreover, they cover the wound and maintain a moist environment at the wound's surface, promoting healing [69]. On the other hand, elastic liposomes and transfersomes squeeze through the intercellular parts of the corneous layer, being able to penetrate intact skin [70]. Ethosomes, due to the presence of ethanol, are soft, malleable vesicles able to penetrate stratum corneum lipids through fluidization, delivering active substances beneath the corneous layer [32]. The reported data exhibit intercellular and transcellular pathways as drug delivery mechanisms of ethosomes [71].

Various studies revealed that nanoparticles might prefer transfollicular and intercellular pathways for skin penetration [72-75]. Moreover, the transfollicular route can supply a deeper penetration of the active substances than the intracellular pathway [76]. In addition, solid lipid nanoparticles express prolonged contact with the corneous layer lipids, facilitating better penetration of liposoluble substances. On the other hand, nanostructured lipid carriers, due to the presence of the liquid lipid in the matrix, are associated with a higher amount of drug skin deposition [77]. Furthermore, lipid nanoparticles can maintain skin hydration due to an occlusive biofilm formed at the surface of the stratum corneum, and its adhesion to the corneous layer stimulates regeneration of the skin lipid film. Moreover, this formed protective lipid film enhances the penetration of the active substances into the skin [41]. The reported data express that nanoparticles with a size less than $20 \mathrm{~nm}$ can potentially permeate intact and injured skin, and those with a size less than $45 \mathrm{~nm}$ but higher than $21 \mathrm{~nm}$ can penetrate only injured skin [78-80]. The anatomical target sites of nanosized-lipid-based drug delivery systems and their penetration pathways into the skin are presented in Figure 3. 


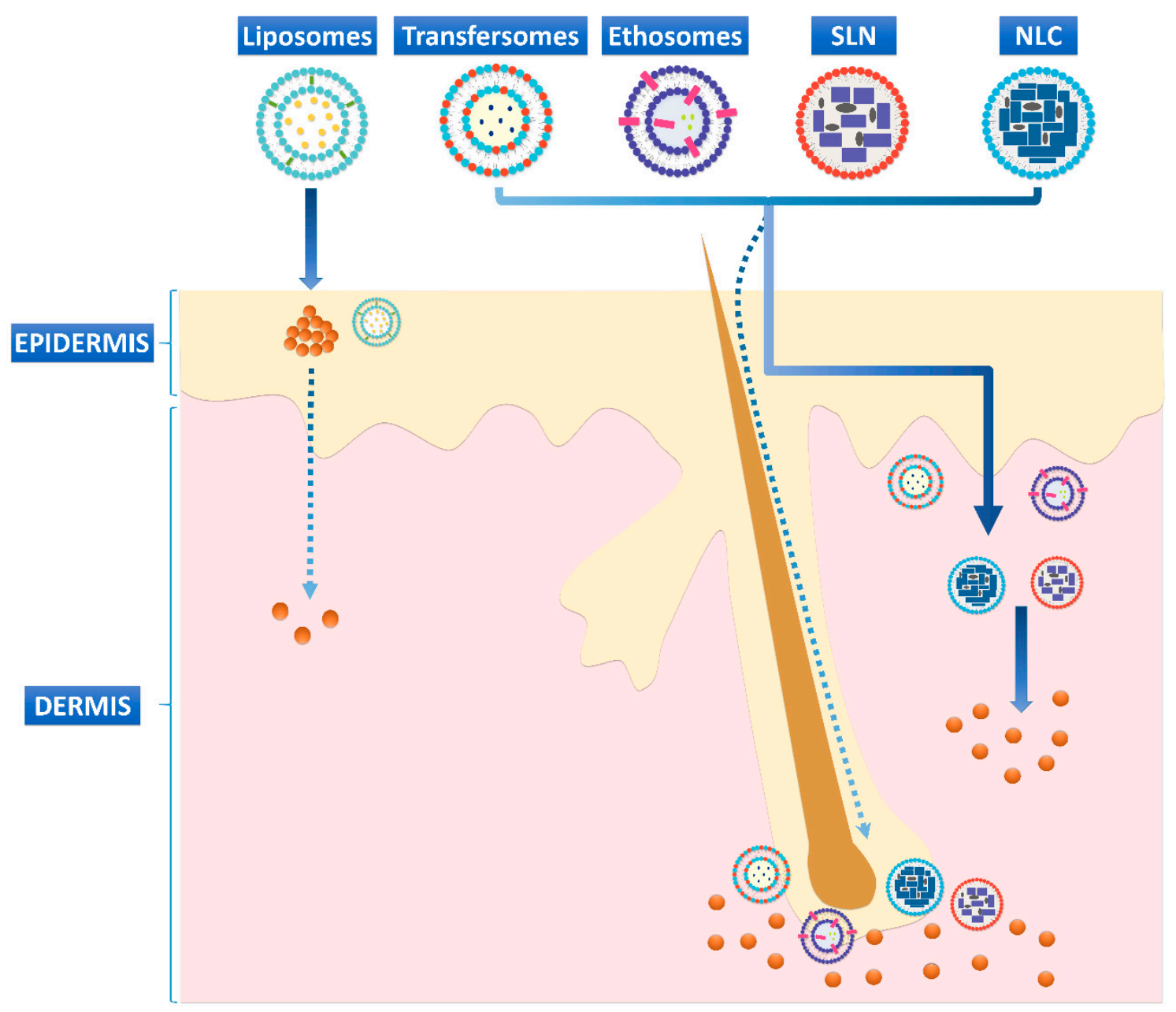

Figure 3. Schematic illustration of the anatomical target sites and skin penetration pathways of the nanosized-lipid-based drug delivery systems. Liposomes penetrate as an intracellular delivery system and deposit the drugs into the stratum corneum. They have poor penetration of the drug into the dermis. Transfersomes squeeze through the intercellular parts of the corneous layer or penetrate through the transfollicular pathway to release the drug into the dermis. Ethosomes penetrate stratum corneum lipids through fluidization, using transfollicular or intercellular pathways and releasing the drug into the dermis. Nanostructured lipid carriers (NLCs) and solid lipid nanoparticles (SLNs) penetrate through intercellular and transfollicular pathways into the dermis.

In the following sections, we will detail the most relevant studies regarding the role of vesicular systems and lipid nanoparticles in wound care, with the most important results being presented in Tables 1 and 2 . 
Table 1. Applications of vesicular systems in wound healing.

\begin{tabular}{|c|c|c|c|c|c|c|}
\hline $\begin{array}{l}\text { Drug Loaded in } \\
\text { Vesicular Systems }\end{array}$ & $\begin{array}{c}\text { Properties } \\
\text { PS = Particle Size }(\mathrm{nm}) \\
\mathrm{EE}=\text { Encapsulation Efficiency }(\%) \\
\mathrm{ZP}=\text { Zeta Potential }(\mathrm{mV})\end{array}$ & \multicolumn{2}{|c|}{ Experimental Design } & Administration & Effects & Refs. \\
\hline \multirow[t]{2}{*}{ Madecassoside } & \multirow{2}{*}{$\begin{array}{c}P S=151 \\
Z P=-54 \\
E E=70.14\end{array}$} & In vivo & $\begin{array}{l}\text { Franz diffusion cell } \\
\text { using full-thickness } \\
\text { dorsal skin excised from } \\
\text { Sprague Dawley rats }\end{array}$ & $\begin{array}{c}0.4 \mathrm{~mL} \text { of madecassoside } \\
\text { liposomes was applied on } \\
\text { the skin tissue }\end{array}$ & $\begin{array}{l}\text { Double emulsion liposomes } \\
\text { loaded with madecassoside } \\
\text { possessed better EE, smaller } \\
\text { size, remarkable stability and a } \\
\text { better capacity to deliver the } \\
\text { active agent at the target site }\end{array}$ & \multirow[t]{2}{*}{ [49] } \\
\hline & & In vivo & $\begin{array}{l}\text { Sprague Dawley rats } \\
\text { with second-degree } \\
\text { burns }\end{array}$ & $\begin{array}{l}\text { Topically, applied once daily } \\
\text { for } 12 \text { days }\end{array}$ & $\begin{array}{l}\text { Better therapeutic wound } \\
\text { healing effect } \\
\text { Significantly improved wound } \\
\text { closure }\end{array}$ & \\
\hline \multirow{3}{*}{$\begin{array}{l}\text { Rosmarinus officinalis } \\
\text { essential oil } \\
\text { and } \\
\text { Salvia triloba essential oil }\end{array}$} & \multirow{3}{*}{$\begin{array}{c}\mathrm{PS}=203.9 \pm 14.13 \\
\mathrm{ZP}=-30 \pm 7.6 \\
\mathrm{EE}=65 \\
\mathrm{PS}=229.6 \pm 15.45 \\
\mathrm{ZP}=-30 \pm 3.9 \\
\mathrm{EE}=57\end{array}$} & \multirow{3}{*}{ In vivo } & $\begin{array}{l}\text { Selectively permeable } \\
\text { bag membrane (cut-off } \\
3-5 \mathrm{KD})\end{array}$ & $\begin{array}{l}200 \mu \mathrm{L} \text { essential oils } \\
\text { dissolved in } 1 \mathrm{~mL} \text { of } \\
\text { methanol }\end{array}$ & $\begin{array}{l}\text { Linear kinetic of essential oils } \\
\text { release, reaching } \sim 40 \% \text { in } 1 \mathrm{~h} \\
\text { and } \sim 100 \% \text { in } 3 \mathrm{~h}\end{array}$ & \multirow{3}{*}{ [81] } \\
\hline & & & $\begin{array}{l}\text { Soybean lipoxygenase } \\
\text { inhibition assay }\end{array}$ & $\begin{array}{l}5 \mathrm{mg} / \mathrm{mL} \text { and } 1 \mathrm{mg} / \mathrm{mL} \text { of } \\
\text { essential oils and liposomes }\end{array}$ & $\begin{array}{c}\text { Moderate anti-inflammatory } \\
\text { activity }\end{array}$ & \\
\hline & & & $\begin{array}{l}\text { Disk inhibition zone } \\
\text { (DIZ) on appropriate } \\
\text { agar plates }\end{array}$ & $\begin{array}{l}\text { Paper disks with } 5 \mu \mathrm{L} \text { of } \\
\text { pure essential oil or essential } \\
\text { oil liposomes }\end{array}$ & $\begin{array}{l}\text { Increased diameter of inhibition } \\
\text { compared with unformulated } \\
\text { EOs } \\
\text { Strong inhibitory effect against } \\
\text { Klebsiella pneumoniae }\end{array}$ & \\
\hline
\end{tabular}


Table 1. Cont.

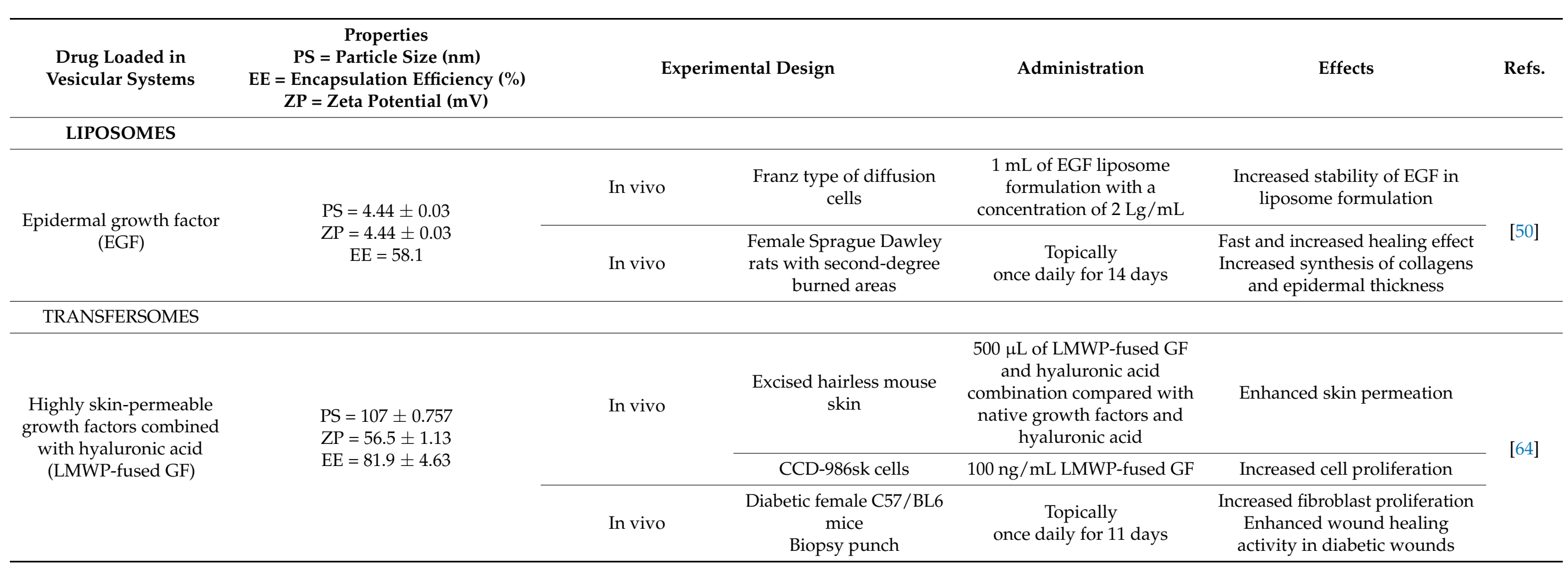


Table 1. Cont.

\begin{tabular}{|c|c|c|c|c|c|c|}
\hline $\begin{array}{l}\text { Drug Loaded in } \\
\text { Vesicular Systems }\end{array}$ & $\begin{array}{c}\text { Properties } \\
\text { PS = Particle Size }(\mathrm{nm}) \\
\mathrm{EE}=\text { Encapsulation Efficiency }(\%) \\
\mathrm{ZP}=\text { Zeta Potential }(\mathrm{mV})\end{array}$ & & ntal Design & Administration & Effects & Refs. \\
\hline \multicolumn{7}{|l|}{ ETHOSOMES } \\
\hline Silver sulfadiazine & $\begin{aligned} \mathrm{PS} & =206.7 \pm 1.18 \\
\mathrm{ZP} & =-67.3 \pm 0.45 \\
\mathrm{EE} & =92.03 \pm 0.79\end{aligned}$ & In vivo & $\begin{array}{c}\text { Dialysis bag diffusion } \\
\text { technique }\end{array}$ & $\begin{array}{l}0.5 \text { mL of formulation } \\
\text { containing silver } \\
\text { sulfadiazine }\end{array}$ & $\begin{array}{c}\text { Reduced drug release correlated } \\
\text { with the increased amount of } \\
\text { lecithin }\end{array}$ & [82] \\
\hline
\end{tabular}


Table 2. Applications of lipid nanoparticles in wound healing.

\begin{tabular}{|c|c|c|c|c|c|c|}
\hline $\begin{array}{l}\text { Drug Loaded in } \\
\text { Lipid Nanoparticles }\end{array}$ & $\begin{array}{c}\text { Properties } \\
\text { PS = Particle Size }(\mathrm{nm}) \\
\mathrm{ZP}=\text { Zeta Potential }(\mathrm{mV}) \\
\mathrm{EE}=\text { Encapsulation Efficiency }(\%)\end{array}$ & \multicolumn{2}{|c|}{ Experimental Design } & Administration & Effects & Refs. \\
\hline \multirow{3}{*}{$\begin{array}{l}\text { Tetrahydro curcumin } \\
\text { (THC) }\end{array}$} & \multirow{3}{*}{$\begin{array}{c}\mathrm{PS}=96.6 \\
\mathrm{EE} \%=65.95 \pm 0.14 \%\end{array}$} & In vivo & $\begin{array}{c}\text { Dialysis membrane with } \\
\text { pore size } 2.4 \mathrm{~nm} \text {, } \\
\text { molecular weight cut off } \\
12-14 \mathrm{Kda}\end{array}$ & $\begin{array}{c}\text { THC-SLNs dispersion }(0.25 \\
\mathrm{mL}) \text {, THC-SLNs gel }(500 \\
\mathrm{mg}) \text {, free THC in gel ( } 500 \\
\mathrm{mg}), \text { all containing } 940 \mu \mathrm{g} \text { of } \\
\text { THC }\end{array}$ & $\begin{array}{c}\text { Higher release of THC incorporated } \\
\text { in SLNs }\end{array}$ & \multirow{3}{*}{ [83] } \\
\hline & & Ex vivo & $\begin{array}{l}\text { Pig ear skin and jacketed } \\
\text { Franz glass diffusion cell }\end{array}$ & $\begin{array}{l}\text { THC-SLNs dispersion }(0.25 \\
\mathrm{mL}), \text { THC-SLNs hydrogel } \\
(500 \mathrm{mg}), \text { THC gel (500 mg), } \\
\text { all containing } 940 \mu \mathrm{g} \text { of THC }\end{array}$ & $\begin{array}{c}\text { Higher skin permeability } \\
\text { Enhanced penetration as a result of } \\
\text { the increased solubility and small } \\
\text { particle size of THC-SLNs }\end{array}$ & \\
\hline & & In vivo & $\begin{array}{l}\text { Male lacca mice } \\
\text { Excisional wound }\end{array}$ & $\begin{array}{c}\text { Topical hydrogel } \\
\text { treatment, started from the } \\
\text { second day until the 14th } \\
\text { day }\end{array}$ & $\begin{array}{l}\text { Increased anti-inflammatory activity } \\
\text { Angiogenic potential } \\
\text { Enhanced collagenous deposition at } \\
\text { the wound site }\end{array}$ & \\
\hline \multirow[b]{2}{*}{$\begin{array}{l}\text { All trans-retinoic acid } \\
\text { (ATRA) }\end{array}$} & \multirow[b]{2}{*}{$\begin{array}{l}\mathrm{PS}=83.0 \pm 6 \\
\mathrm{ZP}=-19 \pm 1 \\
\mathrm{EE}=98 \pm 12\end{array}$} & In vivo & Franz diffusion cells & $\begin{array}{l}500 \mu \mathrm{L} \text { solution of ATRA } \\
(200 \mu \mathrm{g} / \mathrm{mL}) \text { or chitosan } \\
\text { films }\end{array}$ & $\begin{array}{l}\text { SLN-ATRA and chitosan films } \\
\text { revealed a controlled drug release, } \\
\text { essential to reduce local adverse } \\
\text { effects of ATRA }\end{array}$ & \multirow[b]{2}{*}{ [55] } \\
\hline & & In vivo & $\begin{array}{c}\text { Diabetic C57BL/6 male } \\
\text { mice } \\
\text { Excisional wound }\end{array}$ & Topically for 14 days & $\begin{array}{l}\text { Accelerated wound healing } \\
\text { Improved collagen deposition } \\
\text { (especially type III collagen) } \\
\text { Reduced scar and leukocyte } \\
\text { infiltration } \\
\text { Decreased infiltration of neutrophils } \\
\text { and macrophages in the wound } \\
\text { No local adverse reactions }\end{array}$ & \\
\hline
\end{tabular}


Table 2. Cont.

\begin{tabular}{|c|c|c|c|c|c|c|}
\hline $\begin{array}{l}\text { Drug Loaded in } \\
\text { Lipid Nanoparticles }\end{array}$ & $\begin{array}{c}\text { Properties } \\
\text { PS = Particle Size }(\mathrm{nm}) \\
\mathrm{ZP}=\text { Zeta Potential }(\mathrm{mV}) \\
\text { EE = Encapsulation Efficiency }(\%)\end{array}$ & \multicolumn{2}{|c|}{ Experimental Design } & Administration & Effects & Refs. \\
\hline Chamomile oil & $\begin{array}{c}\mathrm{PS}=542.1 \pm 27.5 \\
\mathrm{ZP}=-35.9 \pm 0.602\end{array}$ & In vivo & $\begin{array}{l}\text { Adult male Wistar rats } \\
\text { Excisional wound }\end{array}$ & Topically & $\begin{array}{l}\text { Accelerated wound-healing process } \\
\text { Increased amount of collagen } \\
\text { deposition } \\
\text { Significantly increased level of } \\
\text { TGF-Beta1 } \\
\text { Stimulated the proliferation of } \\
\text { fibroblasts and keratinocytes }\end{array}$ & [84] \\
\hline \multirow{3}{*}{ LL37 and Serpin A1 } & \multirow{3}{*}{$\begin{array}{c}\text { PS of LL37-SLNs }=232.2 \pm 7.8 \\
\text { PS of A1-SLNs }=210 \pm 5.6 \\
\text { EE }>80\end{array}$} & \multirow{2}{*}{ In vivo } & $\begin{array}{c}\text { BJ fibroblasts } \\
\text { Primary human } \\
\text { epidermal keratinocytes }\end{array}$ & $\begin{array}{c}3 \mathrm{mg} / \mathrm{mL} \text { LL37-A1-SLNs } \\
5 \mathrm{mg} / \mathrm{mL} \text { blank SLNs } \\
5 \mu \mathrm{g} / \mathrm{m} \text { LLL37 only } \\
20 \mu \mathrm{g} / \mathrm{mL} \text { A1 only }\end{array}$ & $\begin{array}{l}\text { Faster cell migration and increased } \\
\text { wound closure for LL37 and Serpin } \\
\text { A1 incorporated in SLNs } \\
\text { Decreased collagen type I production }\end{array}$ & \multirow{3}{*}{ [85] } \\
\hline & & & $\begin{array}{l}\text { Evaluation of the } \\
\text { antibacterial activity }\end{array}$ & $\begin{array}{c}2 \mathrm{mg} / \mathrm{mL} \text { LL37 and Serpin } \\
\text { A1 encapsulated in SLNs } \\
5 \mu \mathrm{g} / \mathrm{mL} \text { LL37 } \\
20 \mu \mathrm{g} / \mathrm{mL} \text { Serpin A1 }\end{array}$ & $\begin{array}{l}\text { The combination LL37 and Serpin A1 } \\
\text { had a synergistic antibacterial activity, } \\
\text { especially against } S \text {. aureus and E. coli }\end{array}$ & \\
\hline & & Ex vivo & $\begin{array}{l}\text { Female New Zealand } \\
\text { white rabbits: inner } \\
\text { pinna delipidized skin } \\
\text { Franz diffusion cell }\end{array}$ & 10 mg/mL LL37-A1-SLNs & $\begin{array}{c}\text { Increased permeability across the } \\
\text { impaired skin } \\
\text { Higher deposition of the drugs in the } \\
\text { target area } \\
\text { Protected the peptides from } \\
\text { degradation }\end{array}$ & \\
\hline
\end{tabular}


Table 2. Cont.

\begin{tabular}{|c|c|c|c|c|c|c|}
\hline $\begin{array}{l}\text { Drug Loaded in } \\
\text { Lipid Nanoparticles }\end{array}$ & $\begin{array}{c}\text { Properties } \\
\text { PS = Particle Size }(\mathrm{nm}) \\
\mathrm{ZP}=\text { Zeta Potential }(\mathrm{mV}) \\
\text { EE = Encapsulation Efficiency }(\%)\end{array}$ & \multicolumn{2}{|c|}{ Experimental Design } & Administration & Effects & Refs. \\
\hline \multirow[b]{3}{*}{ 20(S)-protopanaxadiol } & \multirow[b]{3}{*}{$\begin{array}{l}\mathrm{PS}=111.4 \pm 5.9 \\
\mathrm{ZP}=-33.2 \pm 5.5 \\
\mathrm{EE}=97.9 \pm 1.51\end{array}$} & \multirow{2}{*}{ In vivo } & Raw 264.7 cells & $10 \mu \mathrm{M}$ & Anti-inflammatory potential & \multirow[b]{3}{*}{ [56] } \\
\hline & & & HUVEC cells & $2.5 \mu \mathrm{M}$ & Increased angiogenesis activity & \\
\hline & & In vivo & $\begin{array}{l}\text { Male mice (Lepr } \\
\mathrm{db} / \mathrm{JNju}, \mathrm{db} / \mathrm{db} \text { ) with } \\
\text { hyperglycemia } \\
\text { Excisional wound }\end{array}$ & $\begin{array}{l}\text { Topically } \\
\text { Every } 2 \text { days in } 15-\mu \mathrm{L} \text { or } \\
15 \text {-mg doses }\end{array}$ & $\begin{array}{l}\text { Decreased inflammatory infiltration } \\
\text { in the inflammatory stage of wound } \\
\text { healing } \\
\text { Increased angiogenesis during the } \\
\text { proliferation phase } \\
\text { Regulation collagen deposition in the } \\
\text { remodeling phase } \\
\text { Wounds closing without scars }\end{array}$ & \\
\hline \multirow[b]{2}{*}{ Phenytoin } & \multirow[b]{2}{*}{$\mathrm{PS}=178.2 \pm 4.53$} & In vivo & $\begin{array}{l}\text { Modified Franz diffusion } \\
\text { cell with slight } \\
\text { modification using } \\
\text { dyalisis membrane }\end{array}$ & $\begin{array}{c}\text { Hydrogel containing free } \\
\text { drug and Phenytoin-NLC } \\
\text { hydrogel }\end{array}$ & $\begin{array}{c}\text { Phenytoin-NLC hydrogel has shown } \\
\text { a lower release rate than free } \\
\text { phenytoin }\end{array}$ & \multirow[b]{2}{*}{ [58] } \\
\hline & & In vivo & $\begin{array}{c}\text { Prospective } \\
\text { double-blinded, } \\
\text { randomized, controlled } \\
\text { study } \\
27 \text { patients with diabetes } \\
\text { and neuropathic foot } \\
\text { ulceration }\end{array}$ & $\begin{array}{l}\text { Topically } \\
\text { Hydrogel } \\
\text { Twice daily for } \\
8 \text { weeks }\end{array}$ & $\begin{array}{l}\text { Phenytoin-NLC hydrogel was more } \\
\text { effective in wound closure when } \\
\text { compared to free phenytoin } \\
\text { Reduced healing time } \\
\text { No adverse reactions }\end{array}$ & \\
\hline
\end{tabular}


Table 2. Cont.

\begin{tabular}{|c|c|c|c|c|c|c|}
\hline $\begin{array}{l}\text { Drug Loaded in } \\
\text { Lipid Nanoparticles }\end{array}$ & $\begin{array}{c}\text { Properties } \\
\text { PS = Particle Size }(\mathrm{nm}) \\
\mathrm{ZP}=\text { Zeta Potential }(\mathrm{mV}) \\
\text { EE = Encapsulation Efficiency }(\%)\end{array}$ & \multicolumn{2}{|c|}{ Experimental Design } & Administration & Effects & Refs. \\
\hline \multicolumn{7}{|l|}{$\begin{array}{l}\text { Nanostructured lipid } \\
\text { carriers (NLCs) }\end{array}$} \\
\hline \multirow{3}{*}{ LL37 } & \multirow{3}{*}{$\begin{array}{c}\mathrm{PS}=273.6 \pm 27.64 \\
\mathrm{ZP}=-31.63 \pm 1.94 \\
\mathrm{EE}=96.40 \pm 0.41\end{array}$} & \multirow[t]{2}{*}{ In vivo } & $\begin{array}{l}\text { Human foreskin } \\
\text { Fibroblasts: RAW } 264.7 \\
\text { cells }\end{array}$ & $5000 \mathrm{ng} / \mathrm{mL}$ & $\begin{array}{l}\text { Encapsulation of LL37 in NCLs did } \\
\text { not affect its bioactivity }\end{array}$ & \multirow{3}{*}{ [86] } \\
\hline & & & $\begin{array}{l}\text { Evaluation of the } \\
\text { antimicrobial activity }\end{array}$ & $20 \mu \mathrm{g} / \mathrm{mL}$ & $\begin{array}{l}\text { Increased antimicrobial activity } \\
\text { against } E . \text { coli }\end{array}$ & \\
\hline & & In vivo & $\begin{array}{c}\text { Balb / c mice } \\
\text { male } d b / d b \text { mice } \\
\text { Punch biopsy wound }\end{array}$ & $\begin{array}{l}\text { Topically, spread over the } \\
\text { wound bed on days } 1 \text { and } 4 \\
\text { after wound induction }\end{array}$ & $\begin{array}{l}\text { Significantly higher grade of } \\
\text { reepithelization } \\
\text { Accelerated anti-inflammatory effect } \\
\text { Increased collagen deposition }\end{array}$ & \\
\hline \multirow{3}{*}{ Eucalyptus oil } & \multirow{3}{*}{$\begin{array}{c}\mathrm{PS}=220 \text { to } 300 \\
\mathrm{ZP}=-22.07 \pm 0.29 \\
\mathrm{EE}=\sim 100\end{array}$} & \multirow[b]{2}{*}{ In vivo } & $\begin{array}{l}\text { Normal human dermal } \\
\text { fibroblasts from juvenile } \\
\text { foreskin }\end{array}$ & $\begin{array}{l}200 \mu \mathrm{L} \text { nanoparticles } \\
\text { suspensions }\end{array}$ & Increased cell proliferation & \multirow{3}{*}[52]{} \\
\hline & & & $\begin{array}{l}\text { Evaluation of the } \\
\text { antimicrobial activity }\end{array}$ & $\begin{array}{l}\text { Nanoparticles and } \\
\text { eucalyptus oil dispersed in } \\
\text { lecithin solution }\end{array}$ & $\begin{array}{l}\text { Increased antibacterial effect on } \\
\text { Streptococcus pyogenes compared with } \\
\text { free drug and similar antimicrobial } \\
\text { effect on Staphylococcus Aureus } \\
\text { compared with free drug }\end{array}$ & \\
\hline & & In vivo & $\begin{array}{c}\text { Wistar Male rats } \\
\text { Burn injuries followed } \\
\text { by biopsy punch at } 24 \mathrm{~h}\end{array}$ & Topically daily for 18 days & $\begin{array}{c}\text { Decreased lesion area at } 4 \text { days of } \\
\text { treatment } \\
\text { Promoted wound healing }\end{array}$ & \\
\hline
\end{tabular}


Table 2. Cont.

\begin{tabular}{|c|c|c|c|c|c|c|}
\hline $\begin{array}{l}\text { Drug Loaded in } \\
\text { Lipid Nanoparticles }\end{array}$ & $\begin{array}{c}\text { Properties } \\
\text { PS = Particle Size }(\mathrm{nm}) \\
\mathrm{ZP}=\text { Zeta Potential }(\mathrm{mV}) \\
\text { EE = Encapsulation Efficiency }(\%)\end{array}$ & & mental Design & Administration & Effects & Refs. \\
\hline \multicolumn{7}{|l|}{$\begin{array}{l}\text { Nanostructured lipid } \\
\text { carriers (NLCs) }\end{array}$} \\
\hline \multirow[b]{2}{*}{ Peppermint essential oil } & \multirow{2}{*}{$\begin{array}{c}\mathrm{PS}=40-250 \\
\mathrm{ZP}=-10 \text { to }-15 \\
\mathrm{EE}=93.2 \pm 1.2\end{array}$} & In vivo & $\begin{array}{l}\text { Evaluation of the } \\
\text { antimicrobial activity }\end{array}$ & $\begin{array}{c}100 \mu \mathrm{L} \text { peppermint } \\
\text { oil/peppermint oil loaded in } \\
\text { NLCs }\end{array}$ & $\begin{array}{l}\text { Same effect on most bacterial strains } \\
\text { between the encapsulated drug and } \\
\text { the free drug }\end{array}$ & \multirow[b]{2}{*}{ [87] } \\
\hline & & In vivo & $\begin{array}{c}\text { Mice } \\
\text { Punch biopsy }\end{array}$ & $\begin{array}{c}\text { Topically } \\
\text { Gel formulation } \\
\text { Applied once daily }\end{array}$ & $\begin{array}{l}\text { Significantly diminished the infected } \\
\text { wound } \\
\text { Increased wound healing rate } \\
\text { Increased fibroblast proliferation and } \\
\text { collagen synthesis }\end{array}$ & \\
\hline $\begin{array}{l}\text { Epidermal Growth } \\
\text { Factor (EGF) and } \\
\text { Curcumin }\end{array}$ & $\begin{array}{c}\mathrm{PS}=331.8 \mathrm{~nm} \\
\mathrm{ZP}=-6.64 \pm 0.51 \\
\mathrm{EE}=81.1-99.4\end{array}$ & In vivo & $\begin{array}{l}\text { NIH } 3 \text { T3 fibroblasts and } \\
\text { HaCaT keratinocytes }\end{array}$ & $\begin{array}{l}\text { EGF-Cur-NLC (10 ng/mL } \\
\text { EGF and } 100 \mathrm{ng} / \mathrm{mL} \\
\text { curcumin) }\end{array}$ & $\begin{array}{l}\text { Enhanced proliferation of fibroblasts } \\
\text { and keratinocytes }\end{array}$ & [57] \\
\hline
\end{tabular}




\subsection{Vesicular Systems}

\subsubsection{Conventional Liposomes in Wound Healing}

Liposomes are small spherical vesicles prepared based on natural phospholipids, such as lecithin, with a structure similar to most biological membranes' lipids [88] (see Figure 2a). The phosphatidylcholine represents another frequently used phospholipid, which is obtained from soybean or egg yolk. The physicochemical properties of liposomes, such as the lipid composition, particle size, membrane rigidity or elasticity, surface charge, number of lamellae and drug storing potential, determine their stability and drug delivery abilities [89]. Several methods of preparations of liposomes are represented by hand shaking, membrane extrusion, thin-film hydration, sonication or ethanol injection [90]. The stability of the liposomes is fragile, being influenced by several factors such as the composition of the lipid bilayer, the quantity of external water or the interaction between the drug and the bilayer. In addition, the shelf life of liposomes can be affected during flocculation or aggregation processes, modifying their size and stimulating the fusion of the vesicles. Lyophilization, or storage of the liposome in a dry state, is an effective technique to overcome the instability of the liposomes, specifically to develop stable boundaries between the vesicles [91,92]. A maximum drug loading capacity associated with prolonged storage would be around $15-20 \%$ [93].

The amphiphilic property of liposomes helps them to encapsulate both hydrosoluble and liposoluble drugs. Liposomal encapsulation also enhances the solubility and transdermal penetration for some hard-to-dissolve pharmacological agents [68]. Regarding the size of the liposomes, it modifies the capacity of penetration into the skin. Liposomes larger than $600 \mathrm{~nm}$ cannot deliver substances into the deep skin layers, while smaller vesicles can provide maximal penetrability [40]. According to their classification, multilamellar vesicles present a size range of 1-5 $\mu$. Large unilamellar vesicles have a size range between 100 and $250 \mathrm{~nm}$, and small unilamellar vesicles show a size range between 20 and $100 \mathrm{~nm}$ [94].

The encapsulation efficiency (EE\%) is an important quantitative parameter expressing the amount of the active agent enclosed in the nanosized-lipid-based systems. Liposomes present a typical drug delivery EE\% less than 30\% [95].

Another fundamental parameter is the zeta potential, which measures the electrical charge on the particle surface and provides information about particle stability. The surface charge of vesicles plays a crucial role in their capacity to penetrate deeper skin layers. It has been highlighted that cationic vesicles have a higher absorption rate across the skin layers than anionic liposomes [96]. Cationic liposomes can work as gene delivery systems by forming complexes with the negatively charged nucleic acids. Moreover, cationic lipid nanoparticles have been studied widely for small systemic interfering (siRNA) delivery and have shown promising results in topical applications. RNA interference (RNAi) can be a crucial tool for silence-targeted genes, but the poor availability of safe and effective delivery systems has limited its therapeutic use for cutaneous diseases. In this case, topical delivery is preferred over systemic delivery. Striving to manage this problem, scientists have explored nanosized-lipid-based drug delivery systems. For instance, Rabbani et al. developed cationic liposomes and peptide-based ternary complexes to increase the transfection of Keap1 siRNA. This molecule stimulates antioxidant mechanisms and establishes tissue regeneration [97]. Human diabetic ulcers express a significantly reduced micro-RNA-132 compared with normal skin wounds. An effective wound closure, along with an increased proliferation of wound edge keratinocytes and reduced inflammation, has been revealed after local replenishment of microRNA-132 in the wounds of diabetic mice [98]. Furthermore, Li et al. mixed liposome-formulated micro-RNA-132 mimics with pluronic F-127 gel. This mixture was topically applied onto human ex vivo skin wounds immediately after injury, resulting in an increased level of micro-RNA-132 in the wounds a few days after the beginning of treatment. The healing process was reinforced, which greatly accelerated wound closure, repressed inflammation and increased keratinocyte proliferation [99]. 
Encapsulation of adenosine triphosphate (ATP) in unilamellar lipid vesicles was used for intracellular energy delivery and was tested on ear skin wounds in rabbits. The essential finding of this study was the extremely rapid granulation tissue growth in ischemic and non-ischemic rabbit ear skin treated with intracellular ATP liposomes compared with a saline-treated group [100].

The impairment of wound healing is mainly caused by inadequate blood perfusion, leading to hypoxia within the wound area. Buflomedil hydrochloride is a vasoactive drug that has been encapsulated in liposomes, causing significant wound epithelialization and a reduced period until complete wound closure [101]. Topical formulation, applied daily until complete neovascularization, has been shown to be beneficial in wound care, thus overcoming the side effects of systemic administration [101].

In another study, an improved wound closure rate and reduced inflammation were obtained by delivering syndecan- 4 into liposomes along with platelet-derived growth factor $\mathrm{BB}$, all embedded in alginate dressing [102]. Recent studies have highlighted that epidermal growth factor (EGF) or related peptides play essential roles in healing wounds resulting from burn lesions. However, these peptides have shown low stability in conventional formulations. An in vivo experiment evaluated the stability and effects of EGF loaded in liposomes as follows. Researchers inflicted second-degree burn wounds on female Sprague Dawley rats and split them into six groups. The rats treated with a liposome formulation containing $10 \mu \mathrm{g} / \mathrm{mL}$ EGF, applied daily for two weeks, recorded the best healing effect [50]. Furthermore, the same research group performed a study where multilamellar EGF-loaded liposomes carried in chitosan gel were developed and assessed for burn wounds. Chitosan is a polysaccharide with excellent biological properties, such as hemostatic activity, biocompatibility, antimicrobial activity and the capacity to accelerate wound healing when administered as a wound dressing. At the end of the treatment, the EGF-loaded liposome group's epithelization rate was the highest when considering the histochemical results among all the other groups [103].

Regarding natural agents, we found studies that evaluated their incorporation in vesicles as a wound treatment. Essential oils (EO) loaded in vesicular systems represent a practical approach to enhancing their biopharmaceutical properties. Despite the wide use of these plant extracts on account of their antiseptic properties, issues such as high volatility and low stability led to limited use in clinical practice [65]. In an in vivo study, Rosmarinus officinalis and Salvia triloba essential oils were loaded into liposomes. Due to the strength of the anionic charge repulsion into their surfaces and a zeta potential of $-30 \mathrm{mV}$, these systems were highly stable. There was no significant variability in the stability of each formulation. The antimicrobial effect of these vesicles was tested using different bacterial strains. As a result, EO effectively counteracted bacterial growth, with a substantial inhibitory effect on Klebsiella pneumoniae. Additionally, the antioxidant properties of the EO were preserved [81]. Another study loaded liposomes with citral and pompia EO, promoting their dermal delivery and enhancing their antimicrobial activity against all the assayed microorganisms [104].

Liposome encapsulation also exceeded the reduced membrane permeability of a highly potent compound used in treating wounds called madecassoside (MA). Researchers evaluated the potential effects on wound healing of MA liposomes prepared by a double emulsion method. They revealed a formulation with a small particle size, remarkable long-term stability and high EE\%. Moreover, in vivo experiments showed that MA double emulsion liposomes improved transdermal penetration and wound healing [49]. Another study on MA liposomes showed that the storage temperature is essential to its stability. A lower temperature $\left(4^{\circ} \mathrm{C}\right)$ was optimal for the storage of MA liposomes with a higher $\mathrm{EE} \%$ [105]. 
In the section above, we found studies that incorporated vasoactive drugs, genes, plant extracts, intracellular molecules or growth factors in liposomes. Even though liposomes are nontoxic, biodegradable and biocompatible with skin [106], these molecules face significant obstacles to their expansion in clinical use: low stability, low reproducibility and rapid drug leakage [107].

\subsubsection{Ultra-Deformable Liposomes or Transfersomes in Wound Healing}

Currently, conventional liposomes are less utilized as transdermal delivery systems due to the development of new vesicular systems named ultra-deformable liposomes, elastic vesicles or transfersomes [108].

The chemical structure of transfersomes consists of a phospholipid bilayer, an edge activator and water [40] (see Figure 2b). Surfactants such as sodium deoxycholate, sorbitan monostearate, sorbitan monooleate (Span 80), sorbitan monolaurate or polysorbate 80 (Tween 80) are commonly used edge activators [109]. Moreover, Span 80 is more effective than Tween 80 , and sodium deoxycholate provides maximum deformability to the vesicle membrane pores [110]. The evaporation of water when the lipid suspension is dispersed on the skin surface determines the penetration capacity. The elasticity of vesicles helps them deform and penetrate, as intact vesicles, skin pores that are much smaller than their diameters. Edge activators play an important role in this remarkable deformability of transfersomes, having the potential to solubilize and fluidize the skin lipids, leading to a higher permeation capability [111]. Two standard techniques were reported in order to manufacture transfersomes, which are the thin-film hydration and modified handshaking methods. Transfersomes are chemically unstable during storage as a consequence of their propensity to oxidative degradation. Hence, lyophilization is a method used to increase the storage stability of the transfersomes with satisfactory results [112]. In most cases, they present a high EE\% of 90\%, particularly for lipophilic drugs [111], a high drug loading capacity [113] and a size range between 100 and $400 \mathrm{~nm}$ [114].

These novel carriers combine the benefits of traditional liposomes and exhibit more advantages in topical treatment, enabling the controlled release of the active substance and augmenting the stability of unsteady drugs [115].

Several studies have explored the encapsulation of peptides, such as growth factors, to ensure optimal delivery. For instance, recombinant human epidermal growth factor (rhEGF) is an endogenous polypeptide that regulates cell proliferation and differentiation [116]. This peptide can be an excellent formulation for skin conditions such as chronic wounds, diabetic ulcers or burns. Nevertheless, its instability is prone to affect the properties of the product, also diminishing its biochemical actions [117]. A great approach to enhancing their penetration was the encapsulation of rhEGF in transfersomes. The skin penetration of rhEGF was increased using transfersomal rather than non-transfersomal emulgel formulation. In this study, the best formulation of transfersomes was achieved with a vesicle-to-active-ingredient ratio of 200:1. These newly formed vesicles were spherical and unilamellar, with a size range of less than $200 \mathrm{~nm}$ and a zeta potential less than $-30 \mathrm{mV}$, demonstrating great stability, excellent deformability and high entrapment efficiency. The emulgel formulation used in this study can be more advantageous, enhancing the drug stability and release compared with gel base-incorporated active substances [116].

In another experiment on growth factors, a topical delivery system for the lowmolecular-weight-protamine (LMWP)-fused growth factors (GFs) combined with hyaluronic acid (HA) was developed. In this study, cationic elastic liposomes, along with the GF-HA complexes, were explored as better suited carriers in diabetic wound therapy. This formulation allowed for extended exposure of the GF-HA vesicles in the wound bed, reducing the required dose for GFs. Transfersomes containing the LMWP-fused GFs along with HA improved the wound healing capacity in a diabetic mouse model, inducing a decrease in wound size of approximately 65\% [64]. 
Recent research on diabetic rats evaluated the healing capacity of deferoxamine-loaded transfersomes in pressure ulcers. Deferoxamine-loaded transfersomal gel represents a potential type of therapy for treating human diabetic ulcers because it increases the rate of neovascularization, collagen fiber production and the overall healing process of ulcers [118].

Transfersomes can increase the transdermal flux, extend drug release and enhance the site specificity of bioactive molecules [110]. However, transfersomes also have limitations, such as their instability and tendency for oxidative degradation. Another disadvantage is the expensive equipment required for their production [111].

\subsubsection{Ethosomes in Wound Healing}

Ethosomes are updated versions of conventional liposomes and are composed of phospholipids, cholesterol and a large amount of alcohol (20-45\%) [40,109] (see Figure 2c). Their lipid membranes are less tightly packed than other vesicle membranes, allowing them to be more flexible. Commonly used phospholipids for the preparation of ethosomes are phosphatidylcholine, phosphatidic acid, phosphatidylserine and phosphatidylethanolamine. Some preferred alcohols are ethanol and isopropyl alcohol [119]. The presence of ethanol determines a negative surface charge that prevents the aggregation of vesicles due to electrostatic repulsion. Ethanol is an efficient penetration enhancer and, due to its properties, ethosomal formulations have shown higher permeation, more prolonged action and long-term stability in storage [40]. Furthermore, increasing the ethanol concentration increases the EE\% of the ethosomes [120], which is typically reported as high [121].

Ethosomes also improved the access for both highly hydrophobic [122] and highly hydrophilic drugs to the deep skin layers [123]. This improvement of drug permeability is a result of the ethanol effect. The synergy between ethanol and the polar head of the lipid molecules creates increased fluidity and diminished density in the lipid layers, releasing the drug into the deep layers of the skin [124]. The size range of the ethosomes is 103-200 nm, depending on the amount of ethanol [125]. Therefore, the storage stability of the vesicular systems is a significant concern. However, ethosomes present superior stability compared with conventional liposomes [126]. The lyophilization (freeze-drying) process had different results in terms of drug-containing ethosomes. Although the evidence showed no difference before or after this process in a study [127], other authors expressed that this method is suitable to increase the stability of ethosomes [125]. Ethosomes are easy to scale up through the cold process, which is the most-used technique for preparation, or the hot method [125].

Several studies have investigated the relevance of ethosomes in wound-healing treatment and have shown the superior skin delivery of active substances loaded in ethosomes compared with liposomes or classical formulations.

Recent studies found that encapsulated natural substances and antibacterial agents increase their efficacy in the treatment of burn wounds. For instance, curcumin, a natural compound of turmeric, was encapsulated in ethosomes to evaluate its wound-healing effects in rats with second-degree burns [128]. This formulation presented a mean size of the particle of $\sim 120 \mathrm{~nm}$ and an optimum EE\% for curcumin of approximately $85 \%$. The results suggest that curcumin loaded in ethosomes has a potent antibacterial effect, as well as a strong wound-healing capacity better than that of free curcumin, in burn wound therapy [128]. Zhao et al. evaluated the particle sizes and drug release behavior of curcumin loaded in ethosomes and other vesicular systems. Ethosomal curcumin formulation with a mean particle size of $289 \mathrm{~nm}$ presented a higher EE\% and higher skin deposition of curcumin compared with classical liposomes [129].

In another study, ethosomes loaded with silver sulfadiazine (SSD), a topical antibiotic considered the gold standard in burn wounds, were tested in vivo and in vitro to evaluate their capacity to reduce bacterial infections and healing times in second-degree burns [82]. An increased ethanol concentration in this formulation and lecithin levels of $1 \%$ led to a decrease in vesicle size. Moreover, a higher level of lecithin and alcohol enhanced the EE\% and drug release stability. The study results revealed that topical application of the SSD 
ethosome along with Carbopol gel 974 could overcome the disadvantages of commercial cream, enhancing the wound contraction rate in Wistar rats by $30 \%$ compared with the control group. Furthermore, this formulation presented a significant in vivo antimicrobial activity on the tested bacterial strains [82]. A previous study by Jain et al. evaluated an ethosome-loaded Carbopol hydrogel and exposed the suitable physicochemical properties of Carbopol 974, acting as an efficient carrier system for ethosomal vesicles [130]. Skin inflammation involves complex mechanisms that can activate numerous cellular and molecular factors, and maintaining an inflammatory microenvironment, as happens in chronic wounds, can even promote carcinogenic processes. Thus, the identification of new ways of evaluation and modulation of inflammatory reactions in wound-healing phases represent important topics of interest in scientific research [131-133]. A promising therapeutic approach is the transdermal delivery of the nonsteroidal anti-inflammatory drug piroxicam, encapsulated in ethosomes and combined with iontophoresis. This formulation presented particle sizes smaller than $170 \mathrm{~nm}$. Significant differences were found between the transdermal penetration of the free drug and nanoethosomal piroxicam formulation combined with iontophoresis. Furthermore, iontophoresis significantly increased ethosomal piroxicam diffusion compared with the control group [134].

Thymosin $\beta-4$ is a hydrophilic macromolecular protein that plays an essential role in cellular regeneration but has inadequate transdermal permeation and a reduced $\mathrm{EE} \%$. Therefore, researchers have provided a new design for the ethosomal gel system using thymosin $\beta-4$ ethosomes prepared through the ethanol infusion method. This study revealed that ethosomal gel formulation presented a better drug transdermal diffusion rate than the control group and significantly reduced the skin wound healing time [135].

Ethosomes can be a great opportunity for the noninvasive delivery of small-to-largesized active substances [124]. In comparison with other vesicular lipid systems, ethosomes have several advantages, such as enhancing the permeability of a large group of drugs, more efficient delivery to the skin in terms of quantity and depth, a low-risk profile and administration in gel or cream formulations, which leads to better patient compliance [124].

\subsection{Lipid Nanoparticles in Wound Healing}

Lipid nanoparticles have proven to be efficient topical carriers due to their increased biocompatibility and capacity to incorporate several natural and semi-synthetic agents, maximum drug incorporation and wide production capacity. Their occlusive characteristics, based on their lipid structures, minimize cutaneous water loss and increase skin hydration, making them proper carriers for damaged skin. Wound hydration is known as a key factor in accelerating the wound-healing process. Nonetheless, their occlusive effect depends on the lipids' melting point, the incorporated liquid lipids and the size of the formed nanoparticles $[42,136]$. Small-sized particles and low melting points were associated with the maximum occlusion effect [137].

Two generations of lipid nanoparticles are acclaimed, with the first generation being solid lipid nanoparticles (SLNs) and the second generation being nanostructured lipid carriers (NLCs).

\subsubsection{Solid Lipid Nanoparticles in Wound Healing}

SLNs were described as alternative drug delivery systems to emulsions and liposomes. They consist of $0.1-30 \% w / w$ solid lipid dispersed in an aqueous medium and can be stabilized with $0.5-5 \% w / w$ surfactant (see Figure $2 \mathrm{~d}$ ). Several of the solid lipids used are free fatty acids (stearic acid and palmitic acid), waxes (cetyl palmitate), triglycerides (tri-stearin), monoglycerides, diglycerides, fatty alcohols and glycerol esters [45]. The mean particle sizes of SLNs range from 40 to $1000 \mathrm{~nm}$ [138]. They are composed of substances recognized as safe; most lipids are biodegradable, also presenting low local adverse reactions and low cytotoxic effects on the human cells [45]. SLNs showed the ability to shield active substances against physicochemical degradation, also maintaining 
a controlled release over an extended period. Aside from that, they are more affordable, biodegradable and easy to sterilize $[45,139]$.

The reported data showed that SLNs have a typical EE\% between 50\% and 100\% [140], a mean particle size between 50 and $500 \mathrm{~nm}$ [141] and a drug loading capacity up to $33 \%$. During storage, due to its solid lipid structure, the rigid core formed conducts the drug expulsion through the matrix [142]. Hence, the lyophilization process is a suitable method to increase the physical and chemical stability of SLNs [143]. Moreover, they can be easily scaled up to industrial-scale through homogenization at 500 bar pressure [144]. Other available methods to produce SLNs are ultrasonication, double emulsion, high shear homogenization, spray drying methods, solvent injection, melt dispersion or using microemulsions [41,145].

Based on these properties, several studies have investigated the advantages of SLNs for cutaneous application, evaluating their release profile and potential use for woundhealing treatments. Additionally, many studies have used the encapsulation of molecules in SLNs to increase collagen settlement and reduce inflammation. For instance, all-trans retinoic acid (ATRA) is a derivative of vitamin A that has been suggested as a possible efficient wound-healing medication [55]. However, several issues, such as its insolubility in water, instability and the high risk of adverse reactions, have limited the topical use of ATRA. ATRA was encapsulated in SLNs and incorporated in a chitosan film to overcome these problems, presenting a high encapsulation efficiency and controlled drug release. In in vivo studies on diabetic mice, SLNs exhibited accelerated wound healing rates, improved collagen deposition and reduced scar and leukocyte infiltration. Moreover, no local adverse reactions were observed [55].

An in vivo study on $\mathrm{HaCaT}$ cells highlighted that tristearin encapsulation and hyaluronic acid in SLNs significantly improved wound healing [146].

Regarding chamomile oil, one of the most frequently used herbs with a great effect in stimulating wound healing, it has a limited application as a topical treatment due to its inadequate tissue permeability and rapid degradation after exposure to environmental factors. Encapsulation of chamomile oil in SLN (CM-SLN) revealed an enhancement in wound contraction and accelerated healing activity, restoring skin integrity. Moreover, rats treated with CM-SLNs presented higher levels of transforming growth factor- $\beta 1$ (TGFB1) compared with the control group, with this factor playing a pivotal role in fibroblast contraction and collagen settlement [84].

In another complex study with in vivo, ex vivo and in vitro research, tetrahydrocurcumin (THC), a substance with great antioxidant and anti-inflammatory features, was incorporated in SLNs in order to elevate its topical bioavailability. The results indicated a faster and better wound healing rate in the mice treated with THC-SLN gel. This new formulation showed higher skin permeability and extended the drug release for more than $24 \mathrm{~h}$. THC-SLN gel can be a safer alternative to the currently available products, increasing patient compliance with treatment due to its non-staining, non-irritating, non-greasy and easily spreadable properties [83].

Concerning drugs with antimicrobial activity, we found many studies that used SLN encapsulation to enhance this effect. Cefadroxil-loaded SLN-based topical gels were evaluated for in vivo wound healing activity in male rats. This formulation could eradicate bacterial growth and effectively treat an infectious wound in a short span of time [147].

Other research evaluated the potential therapeutic effects of combining LL37 and Serpin A1 into a single nanoparticle formulation using SLNs as a delivery system. LL37 is a human peptide with broad antimicrobial activity. It also plays an efficient role in angiogenesis and epithelial cell migration. Regarding Serpin A1, also known as $\alpha 1$-antitrypsin, it is a major physiological elastase inhibitor and immunomodulator. The in vivo experiments on BJ fibroblasts and keratinocytes showed an accelerated wound healing effect, stimulating wound closure. Moreover, this formulation increased antibacterial activity, especially against $S$. aureus and E. coli, and presented anti-inflammatory effects [85]. 
As mentioned before, one of the preferred antimicrobial agents in burn wound therapy is silver sulfadiazine (SSD). However, in several cases, the wound-healing process was delayed due to its toxicity on fibroblasts and keratinocytes [148]. Hence, a chitosan gel rich in SLN-SSD along with deoxyribonuclease-I was tested and showed an essential cytoprotective activity with fibroblasts. Moreover, this new formulation improved the therapeutic effect of SSD on biofilm resistance associated with wound infection and significantly increased the wound closure [145]. Another study evaluated curcumin and ampicillin SLNs incorporated in semi-solid formulations (ointments and gels) as potential forms of therapy in burn wounds. Both SLN-based formulations presented a mean particle size of $112-121 \mathrm{~nm}$, low zeta potential and increased wound healing rate in vivo without any sign of toxicity. Moreover, they exhibited a synergistic antibacterial effect [149].

A recent study evaluated another antiseptic drug used in wound healing therapy, povidone-iodine, incorporated in SLNs. The povidone-iodine encapsulation in SLNs created a formulation with good stability, a mean particle size of $285.4 \mathrm{~nm}$ and an optimal $\mathrm{EE} \%$ [150].

Topically applied opioids have shown an enhancing keratinocyte migration effect, which can hasten wound healing, but their poor concentration at the target site failed to maintain pain control. Therefore, researchers attempted to improve wound healing through a new human-based, 3D wound-healing model using morphine-loaded SLNs with a mean size of about $180 \mathrm{~nm}$. This unique formulation, compared with the conventional one, improved wound closure, with lower cytotoxicity and irritation risk, associated with a prolonged morphine release [151].

Valsartan, an antagonist of the angiotensin 1-receptor, was used in an experimental study to increase the diabetic wound-healing process. Based on previous studies, which reported its efficacy in chronic diabetic wounds [152,153], Valsartan was encapsulated in SLNs and integrated into a gel composition in order to improve its dermal permeability. Evaluation of valsartan SLNs showed a small particle size, sustained drug release and high $\mathrm{EE} \%$. In vivo investigation revealed complete healing of the diabetic ulcers in rats in 12 days [154].

Even though SLNs have broad applicability in wound-healing therapy, these nanoparticles have encountered several disadvantages, such as a propensity to gelation, a low incorporation rate due to their crystalline structure or lipid particle growth [42], thus encouraging further research for the discovery of new, more efficient carriers.

\subsubsection{Nanostructured Lipid Carriers in Wound Healing}

NCLs represent the second generation of lipid nanoparticles [41] and are produced by employing blends of solid and liquid lipids (oils), the combination thereof being solid at body temperature (see Figure 2e). To acquire the blends for the particle matrix, solid lipids are mixed with liquid lipids, ideally at a ratio of 70:30 up to a ratio of 99.9:0.1 [138]. Liquid lipid incorporation generates changes in the solid lipid structure, leading to a less ordered crystalline arrangement that averts drug leakage, supplies a high drug load and has great stability during storage [43,142]. Moreover, these nanocarriers possess the ability to deliver both hydrophilic and lipophilic drugs. Hence, they have gained wide applicability in wound-healing treatment. The manufacturing process of NCLs is similar to that used for SLNs. It is noteworthy that they are easy to scale up through high-pressure homogenization, which is the first choice for the method of production [155]. In addition, the freeze-drying process has been investigated for several molecules encapsulated into NCL with satisfactory results in terms of stability [156-159]. NCLs have a typical EE\% of NCLs around $85 \%$, a high drug loading capacity [160] and a mean particle size between 50 and $300 \mathrm{~nm}$ [161].

Given their small size, the contact of NCLs with the stratum corneum is enhanced, and a higher quantity of active agents penetrates through the skin. Thus, NLCs are adequate to enlarge the spectrum of drug delivery systems and surpass various disadvantages concerning conventional nanosized-lipid-based carriers. 
NLCs are viewed as an improved generation of SLNs due to several advantages: the increased loading capability of active substances, enhanced stability, reduced risk of drug extrusion and improved overall benefit/risk ratio. In terms of biotoxicity and the action mechanism, no significant differences have been found between SLNs and NCLs [162].

However, the incorporation of drugs in NCLs can be an innovative and suitable approach to overcome SLN formulation limitations. Thus, a comparison between SLN and NCL encapsulation of RhEGF showed an EE\% higher in NCL-rhEGF than SLN-rhEGF. Nevertheless, there were no differences between the uptake capacity of SLN-rhEGF and that of NLC-rhEGF in the cell cultures being studied. Both doses of SLN-rhEGF and NLCrhEGF achieved significantly higher wound area reduction than the empty nanoparticle control group. In this study, the bioactivity of the nanoparticle formulations was better in all of the study cell cultures than that of the free rhEGF [163]. Another in vivo and in vitro study compared the effect of SLNs and NLCs loaded with eucalyptus oil or rosemary oil. The oils encapsulated in SLNs showed poor bio-adhesion properties compared with the oils encapsulated in NCLs. This result was an effect of the olive oil presented in the NCL composition, known for its excellent proliferation improvement. Furthermore, eucalyptus oil encapsulated in NCLs, based on olive oil, achieved the best outcome in the proliferation and cell migration tests [52].

As was previously stated, LL37 is an antimicrobial agent produced by human skin which impacts the wound-healing process. In an interesting study, researchers encapsulated LL37 in NLCs to optimize its administration in terms of the dose, delivery pattern and lack of side effects. The particle size of NLCs is a critical factor in determining the rate of drug release and drug absorption. In this study, the obtained NLC formulation revealed the optimal physicochemical properties allowing for better drug release and absorption. Topical administration of LL37-loaded NCLs improved wound healing in terms of the wound closure rate, re-epithelialization and inflammation diminishment compared with free LL37 administration. LL37-loaded NCLs also showed significant antimicrobial effects [86].

Various studies have evaluated the potential of nanoparticles to enhance the bioavailability of natural antimicrobial agents such as EO. For instance, in vivo and in vitro research assessed the efficiency of eucalyptus essential oil loaded in NCLs as potential therapy for skin wounds. NCLs were prepared with cocoa butter (solid lipid) and olive oil (liquid lipid). As a surfactant, lecithin was used to increase stability and prevent aggregation. This formulation increased the bioavailability and efficiency of eucalyptus oil regarding antimicrobial effects and proliferation enhancement. A high level of oleic acid present in olive oil could be the reason for these better effects [52]. Another recent study evaluated the efficiency of peppermint essential oil loaded in NLCs. Peppermint oil loaded in NLCs presented an optimal EE\% and particle size and was better than free peppermint oil in terms of neovascularization, the wound contraction ratio and re-epithelialization. The in vivo study results emphasized significant antibacterial activity against $S$. epidermidis, $S$. aureus, L. monocytogenes, E. coli and P. aeruginosa species [87]. Mentha pulegium, another essential oil with antiseptic and anti-oxidant effects, was also encapsulated in NCLs, and in vivo research showed an important effect against the same bacterial species. Moreover, an in vivo study on BALB/c mice showed that this new formulation reduced the inflammatory phase and accelerated wound healing [164].

Another concern is the oxidative stress associated with chronic inflammation. Oxidative stress is caused by an imbalance between the production of pro-oxidants on the one hand and the capacity of a biological system for the rapid detoxification of free radicals on the other. Oxidative stress is involved in various conditions affecting the skin [165-168] and also is frequently encountered in association with diabetes-induced chronic wounds [169]. 
A wound-healing natural compound with bifunctional properties that can respond to oxygen species and increases antioxidant enzyme production is curcumin (diferuloylmethane), an active substance of turmeric. While various studies in the last decade have shown numerous properties of curcumin, such as anti-inflammatory, antineoplastic or antimicrobial effects, its clinical applications are limited due to its low bioavailability caused by reduced water solubility and stability [170]. Hence, encapsulation of curcumin in nanoparticles was investigated in order to increase its delivery capacity. A recent article evaluated the encapsulation of curcumin and epidermal growth factor (EGF) in NCLs, showing excellent results in stimulating wound healing in a diabetic murine model. EGF plays a paramount role in cell proliferation and the migration of fibroblasts and keratinocytes, and its administration into wounds leads to rapid re-epithelialization and reduces the risk of infection. In vivo research showed better cell migration when NCLs were loaded with both EGF and curcumin. The in vivo studies on diabetic rats revealed a shorter half-healing time associated with this formulation [57].

Melatonin, a molecule known for its anti-oxidant and anti-inflammatory effects, was investigated in several studies for its possible role in wound dressings [171,172]. Recently, a group of researchers developed a hybrid system of melatonin integrated into NLC-loaded, chitosan-based microspheres, a wound-dressing innovation for moderate exuding wounds. Melatonin NCLs presented a small size particle, a positive zeta potential, a great $\mathrm{EE} \%$ and a sustained drug release. Furthermore, in vivo research manifested antimicrobial effects against planktonic bacteria and Staphylococcus aureus [171].

Additional studies have explored the potential of various drugs incorporated in NCLs to decrease inflammation. For instance, in interesting research, thymol, a compound with anti-inflammatory properties, was encapsulated in NCLs to enhance its bioavailability. The study on the murine skin inflammation model revealed that NCL-thymol had stronger anti-inflammatory effects than free thymol [173].

A molecule widely used for treating hemorrhage, blood stasis, bruises, swelling and pain is 20(S)-protopanaxadiol. Studies also reported its effectiveness in diabetic wound healing, given its anti-inflammatory and pro-neovascularization effects. Contrary to these great properties, its applicability in commercial use is limited due to its low solubility. Sun et al. developed a new formulation consisting of silicone elastomer, a polymer reported as being effective in wound healing [174], and 20(S)-protopanaxadiol loaded in NLCs. 20(S)-protopanaxadiol-NCLs resulted in a good EE\% and sustained drug release properties. Aside from that, the in vivo studies showed the anti-inflammatory potential of this new formulation. In vivo experiments on a murine model revealed the enhancement of all wound-healing phases, the regulation of collagen settlement, inflammation decreases and angiogenesis promotion [56].

A recent study evaluated the efficacy of phenytoin loaded in NCLs as a topical treatment for patients with neuropathic diabetic foot ulcerations. Previous experimental research has emphasized that topical phenytoin can stimulate collagen synthesis, improve fibroblast proliferation and enhance wound healing. Still, local adverse reactions associated with commercially available products have restricted its application. In this study, the application of phenytoin loaded in NCLs has shown a more extended release of the active substance, leading to a significant reduction in wound size and healing time [58].

NLCs represent a chemically and physically stable drug delivery system with increased drug loading ability and enhanced bioavailability. The aforementioned properties proved the ability to overcome the shortcomings of SLNs, the first generation of lipid nanoparticles.

\section{Future Perspectives}

Nanosized-lipid-based drug delivery systems have proven to be an area of active research in wound care, providing efficient topical formulations in different types of wounds such as burn wounds or diabetic chronic wounds. However, new innovative approaches are needed to overcome current limitations. 
Nanosized-lipid-based drug delivery systems have been validated for nucleic acid delivery in many areas of medical research, such as oncology, rare diseases or infectious diseases, enabling the release of the first commercial synthetic short interfering RNA (siRNA) drug [175-177]. Furthermore, ionizable cationic lipid nanoparticles were a breakthrough in these fields, overcoming previous issues with delivering siRNA into cells.

Nucleic acids such as microRNA or siRNA have essential roles in wound-healing phases, such as promoting keratinocyte growth, regulating the inflammatory process, angiogenesis and promoting proliferation, and they have been correlated with abnormalities in their regulations concerning chronic wounds or abnormal scars $[176,178]$. Many different types of microRNA can be used in wound care, targeting pathways involved in scarless healing such as transforming growth factor $\beta$ or SMAD proteins [179-181].

As we previously stated, several studies have explored lipid nanoparticles loaded with nucleic acids in wound care. A topical treatment for diabetic wound healing was optimized using cationic lipid nanoparticles combined with an edge activator sodium cholate, resulting in a stable lipoproteoplex nanoparticle to increase the topical delivery of siRNA [97]. However, the precise mechanism of the cellular uptake of nucleic acids is still unknown. That notwithstanding, some studies reported that the size of the nanoparticle might influence the mechanism. For instance, a size range between 4 and $10 \mathrm{~nm}$ leads to direct penetration of the nanoparticles through the cell membrane compared with particles with a size range between 10 and $120 \mathrm{~nm}$, which may be delivered through endocytosis [182]. In vivo research on diabetic mice showed excellent penetration of the siRNA nanoparticle in the target site with an ongoing deposition of the substance five days after administration, which led to accelerated wound closure. Another important aspect was the low cytotoxic in vivo effect of the formulation, making it a safe and viable form of treatment of a diabetic wound [97].

Another approach to lipid nanoparticles loaded with nucleic acids was to develop an excellent formulation for chronic ischemic wounds associated with peripheral vasculopathy and a high level of micro-RNA-210. This formulation succeeded in decreasing the level of micro-RNA-210, which has been correlated with a reduced rate of keratinocyte proliferation [183]. Furthermore, the same research group explored the application of topical, lyophilized, keratinocyte-targeted lipid nanoparticles loaded with locked nucleic acidmodified anti-microRNA in burn wound therapy. The results of the in vivo studies on mice exhibited an accelerated wound closure rate. It should be noted that in this formulation, the lipid nanoparticles were lyophilized to extend the storage stability [184]. Another study previously presented showed the important role of micro-RNA-132 in wound healing [99].

Based on their essential role in maintaining an optimal wound healing environment, topically delivering nucleic acids can be a suitable formula in wound care to avoid systemic toxicity and maximize therapeutic potential [185-187]. However, further in vivo research in this field should be embraced, including nanosized-lipid-based drug delivery systems.

Another interesting topic for further research is the lipid-polymer hybrid nanoparticle (LPN) technology. This novel technology combines the liposome and polymeric nanoparticle properties formed by a core-shell structure with a lower rate of drug leakage, high bioavailability and storage stability [188]. Several in vivo studies exhibited excellent results in drug delivery [189-191]; thus, they have possible applications in wound care. For instance, to treat skin inflammation, Desai et al. encapsulated capsaicin and anti-TNF $\alpha$ in novel cyclic cationic head LPN. The study showed that this formulation was able to efficiently penetrate deep skin layers, delivering active molecules such as anti-TNF $\alpha$ and capsaicin with no cytotoxic effects [192]. Another work designed a new approach for fusidic acid using LPNs in order to encounter MRSA burn wound infections. This study showed excellent results regarding permeability, microbial activity and wound closure compared with conventional formulations [193]. The fusidic acid was also encapsulated in LPNs by other authors, with similar results [194]. The applicability of LPNs to overcome burn wound infection has been reinforced by another study that used them to deliver norfloxacin [195]. 
Scaling up the nanosized-lipid-based drug delivery systems is another challenge. Reported data showed that vesicular systems, such as liposomes, are difficult to scale up or require expensive methods compared with lipid nanoparticles, which are easy to scale up $[196,197]$. However, a suitable process for this is represented by hot or cold high-pressure homogenization [162].

Another important topic for future development is to translate nanosized-lipid-based drug delivery systems into clinical practice and provide reliable large-scale manufacturing. Thus, the comprehensive research on clinical trials in different types of wounds comparing the efficiency of different topical formulations with conventional treatments is imperative to obtain more information about possible adverse reactions in human subjects and develop newly approved therapies in wound care.

\section{Conclusions}

The applications of nanosized-lipid-based drug delivery systems in wound care showed potential in overcoming impediments such as the inadequate bioavailability of active agents with low solubility. Furthermore, they can increase the stability of drugs used in wound-healing therapy, with better efficacy and insignificant adverse effects compared with conventional formulations. Most of the encapsulated drugs presented in this review exhibited an improvement in the wound healing rate correlated with their physiochemical properties. Nanosized-lipid-based drug delivery systems can also increase the drug concentrations in the treated skin area and enhance the efficacy of wound-healing therapies.

Further studies should continue the assessment of nanosized-lipid-based drug delivery systems in order to improve skin permeability for pharmacological substances and achieve increased bioavailability and better control of the drug release, providing the clinician with more effective forms of therapy for wound care.

Author Contributions: Conceptualization, A.-M.M., C.C.; methodology, A.-M.M. and C.C.; writingoriginal draft preparation, A.-M.M., C.C., M.T., S.R.G., C.M., M.M.C., T.V.C., D.C., D.A.C., I.A.B., C.S. and A.C.; writing-review and editing, A.-M.M., C.C., M.T. and A.C.; supervision, C.C.; project administration, C.C. All authors have read and agreed to the published version of the manuscript.

Funding: This research and the APC were partially funded by the Romanian Ministry of Research and Innovation, CCCDI-UEFISCDI, [project number 61PCCDI2018 PN-III-P1-1.2-PCCDI-2017-0341], within PNCDI-III.

Institutional Review Board Statement: Not applicable.

Informed Consent Statement: Not applicable.

Conflicts of Interest: The authors declare no conflict of interest. The funders had no role in the design of the study; in the collection, analyses, or interpretation of data; in the writing of the manuscript, or in the decision to publish the results.

\section{References}

1. Ellis, S.; Lin, E.J.; Tartar, D. Immunology of Wound Healing. Curr. Dermatol. Rep. 2018, 7, 350-358. [CrossRef] [PubMed]

2. Rodrigues, M.; Kosaric, N.; Bonham, C.A.; Gurtner, G.C. Wound Healing: A Cellular Perspective. Physiol. Rev. 2019, 99, 665-706. [CrossRef]

3. Werner, S.; Krieg, T.; Smola, H. Keratinocyte-Fibroblast Interactions in Wound Healing. J. Investig. Dermatol. 2007, 127, 998-1008. [CrossRef] [PubMed]

4. Gurtner, G.C.; Werner, S.; Barrandon, Y.; Longaker, M.T. Wound Repair and Regeneration. Nature 2008, 453, 314-321. [CrossRef] [PubMed]

5. Tottoli, E.M.; Dorati, R.; Genta, I.; Chiesa, E.; Pisani, S.; Conti, B. Skin Wound Healing Process and New Emerging Technologies for Skin Wound Care and Regeneration. Pharmaceutics 2020, 12, 735. [CrossRef] [PubMed]

6. Li, J.; Chen, J.; Kirsner, R. Pathophysiology of Acute Wound Healing. Clin. Dermatol. 2007, 25, 9-18. [CrossRef]

7. Petca, A.; Negoita, S.; Petca, R.-C.; Calo, O.; Diana Sinescu, R. Ether-Based Polyurethane Foam for Vacuum-Assisted Closure (V.A.C.) of Complicated Postoperative Abdominal Wound Dehiscence. Mater. Plast. 2020, 57, 32-38. [CrossRef]

8. Matei, A.-M.; Draghici-Ionescu, A.-M.; Cioplea, M.; Zurac, S.; Boda, D.; Serban, I.; Caruntu, C.; Ilie, M.; Gyula, L. Skin Endometriosis: A Case Report and Review of the Literature. Exp. Ther. Med. 2021, 21, 1-5. [CrossRef] 
9. Fatima, K.; Khanani, S. Scar Endometriosis: An Entity Not to Be Forgotten. J. Pak. Med. Assoc. 2017, 67, $140-142$.

10. Han, G.; Ceilley, R. Chronic Wound Healing: A Review of Current Management and Treatments. Adv. Ther. 2017, 34, 599-610. [CrossRef]

11. Lindholm, C.; Searle, R. Wound Management for the 21st Century: Combining Effectiveness and Efficiency. Int. Wound J. 2016, 13, 5-15. [CrossRef] [PubMed]

12. Sen, C.K.; Gordillo, G.M.; Roy, S.; Kirsner, R.; Lambert, L.; Hunt, T.K.; Gottrup, F.; Gurtner, G.C.; Longaker, M.T. Human Skin Wounds: A Major and Snowballing Threat to Public Health and the Economy: PERSPECTIVE ARTICLE. Wound Repair Regen. 2009, 17, 763-771. [CrossRef] [PubMed]

13. Menke, N.B.; Ward, K.R.; Witten, T.M.; Bonchev, D.G.; Diegelmann, R.F. Impaired Wound Healing. Clin. Dermatol. 2007, 25, 19-25. [CrossRef] [PubMed]

14. Sen, C.K. Human Wounds and Its Burden: An Updated Compendium of Estimates. Adv. Wound Care 2019, 8, 39-48. [CrossRef] [PubMed]

15. Vowden, K.; Vowden, P.; Posnett, J. The Resource Costs of Wound Care in Bradford and Airedale Primary Care Trust in the UK. J. Wound Care 2009, 18. [CrossRef]

16. Eming, S.A.; Martin, P.; Tomic-Canic, M. Wound Repair and Regeneration: Mechanisms, Signaling, and Translation. Sci. Transl. Med. 2014, 6, 265sr6. [CrossRef] [PubMed]

17. Brem, H.; Tomic-Canic, M. Cellular and Molecular Basis of Wound Healing in Diabetes. J. Clin. Investig. 2007, 117, 1219-1222. [CrossRef]

18. Grey, J.E.; Enoch, S.; Harding, K.G. Wound Assessment. BMJ 2006, 332, 285-288. [CrossRef]

19. Bock, O.; Schmid-Ott, G.; Malewski, P.; Mrowietz, U. Quality of Life of Patients with Keloid and Hypertrophic Scarring. Arch. Dermatol. Res. 2006, 297, 433-438. [CrossRef]

20. Bijlard, E.; Kouwenberg, C.A.E.; Timman, R.; Hovius, S.E.R.; Busschbach, J.J.V.; Mureau, M.A.M. Burden of Keloid Disease: A Cross-Sectional Health-Related Quality of Life Assessment. Acta Derm. Venereol. 2017, 97, 225-229. [CrossRef]

21. Lyons, A.B.; Peacock, A.; Braunberger, T.L.; Viola, K.V.; Ozog, D.M. Disease Severity and Quality of Life Outcome Measurements in Patients with Keloids: A Systematic Review. Dermatol. Surg. 2019, 45, 1477-1483. [CrossRef]

22. Armstrong, D.G.; Wrobel, J.; Robbins, J.M. Guest Editorial: Are Diabetes-Related Wounds and Amputations Worse than Cancer? Int. Wound J. 2007, 4, 286-287. [CrossRef]

23. Partridge, L.; Gems, D. Mechanisms of Ageing: Public or Private? Nat. Rev. Genet. 2002, 165-175. [CrossRef] [PubMed]

24. Czajkowska-Kośnik, A.; Szekalska, M.; Winnicka, K. Nanostructured Lipid Carriers: A Potential Use for Skin Drug Delivery Systems. Pharmacol. Rep. 2019, 71, 156-166. [CrossRef]

25. Korrapati, P.S.; Karthikeyan, K.; Satish, A.; Krishnaswamy, V.R.; Venugopal, J.R.; Ramakrishna, S. Recent Advancements in Nanotechnological Strategies in Selection, Design and Delivery of Biomolecules for Skin Regeneration. Mater. Sci. Eng. C 2016, 67, 747-765. [CrossRef] [PubMed]

26. Hamdan, S.; Pastar, I.; Drakulich, S.; Dikici, E.; Tomic-Canic, M.; Deo, S.; Daunert, S. Nanotechnology-Driven Therapeutic Interventions in Wound Healing: Potential Uses and Applications. ACS Cent. Sci. 2017, 3, 163-175. [CrossRef] [PubMed]

27. Pachuau, L. Recent Developments in Novel Drug Delivery Systems for Wound Healing. Expert Opin. Drug Deliv. 2015, 12, 1895-1909. [CrossRef]

28. Johnson, N.; Wang, Y. Drug Delivery Systems for Wound Healing. Curr. Pharm. Biotechnol. 2015, 16, 621-629. [CrossRef]

29. Khan, I.; Saeed, K.; Khan, I. Nanoparticles: Properties, Applications and Toxicities. Arab. J. Chem. 2019, 12, 908-931. [CrossRef]

30. Monteiro, N.; Martins, A.; Reis, R.L.; Neves, N.M. Liposomes in Tissue Engineering and Regenerative Medicine. J. R. Soc. Interface 2014, 11, 20140459. [CrossRef]

31. Geusens, B.; Strobbe, T.; Bracke, S.; Dynoodt, P.; Sanders, N.; Van Gele, M.; Lambert, J. Lipid-Mediated Gene Delivery to the Skin. Eur. J. Pharm. Sci. 2011, 43, 199-211. [CrossRef] [PubMed]

32. Hua, S. Lipid-Based Nano-Delivery Systems for Skin Delivery of Drugs and Bioactives. Front. Pharmacol. 2015, 6, 2011-2015. [CrossRef]

33. Xie, G.; Lu, W.; Lu, D. Penetration of Titanium Dioxide Nanoparticles through Slightly Damaged Skin in Vitro and in Vivo. J. Appl. Biomater. Funct. Mater. 2015, 13, e356-e361. [CrossRef]

34. Mauro, M.; Crosera, M.; Monai, M.; Montini, T.; Fornasiero, P.; Bovenzi, M.; Adami, G.; Turco, G.; Filon, F.L. Cerium Oxide Nanoparticles Absorption through Intact and Damaged Human Skin. Molecules 2019, 24, 3759. [CrossRef]

35. Jain, S.; Patel, N.; Shah, M.K.; Khatri, P.; Vora, N. Recent Advances in Lipid-Based Vesicles and Particulate Carriers for Topical and Transdermal Application. J. Pharm. Sci. 2017, 106, 423-445. [CrossRef]

36. Shrestha, H.; Bala, R.; Arora, S. Lipid-Based Drug Delivery Systems. J. Pharm. 2014, 2014, 1-10. [CrossRef] [PubMed]

37. Jain, S.; Jain, V.; Mahajan, S.C. Lipid Based Vesicular Drug Delivery Systems. Adv. Pharm. 2014, 2014, 1-12. [CrossRef]

38. Verma, S.; Singh, S.; Syan, N.; Mathur, P.; Valecha, V. Nanoparticle Vesicular Systems: A Versatile Tool for Drug Delivery. J. Chem. Pharm. Res. 2010, 2, 496-509.

39. Duan, Y.; Dhar, A.; Patel, C.; Khimani, M.; Neogi, S.; Sharma, P.; Siva Kumar, N.; Vekariya, R.L. A Brief Review on Solid Lipid Nanoparticles: Part and Parcel of Contemporary Drug Delivery Systems. RSC Adv. 2020, 10, 26777-26791. [CrossRef]

40. Sala, M.; Diab, R.; Elaissari, A.; Fessi, H. Lipid Nanocarriers as Skin Drug Delivery Systems: Properties, Mechanisms of Skin Interactions and Medical Applications. Int. J. Pharm. 2018, 535, 1-17. [CrossRef] [PubMed] 
41. Müller, R.H.; Shegokar, R.; Keck, C.M. 20 Years of Lipid Nanoparticles (SLN \& NLC): Present State of Development \& Industrial Applications. Curr. Drug Discov. Technol. 2011, 8, 207-227. [CrossRef]

42. Müller, R.H.; Radtke, M.; Wissing, S.A. Solid Lipid Nanoparticles (SLN) and Nanostructured Lipid Carriers (NLC) in Cosmetic and Dermatological Preparations. Adv. Drug Deliv. Rev. 2002, 54, S131-S155. [CrossRef]

43. López-García, R.; Ganem-Rondero, A. Solid Lipid Nanoparticles (SLN) and Nanostructured Lipid Carriers (NLC): Occlusive Effect and Penetration Enhancement Ability. J. Cosmet. Dermatol. Sci. Appl. 2015, 05, 62-72. [CrossRef]

44. Prow, T.W.; Grice, J.E.; Lin, L.L.; Faye, R.; Butler, M.; Becker, W.; Wurm, E.M.T.; Yoong, C.; Robertson, T.A.; Soyer, H.P.; et al. Nanoparticles and Microparticles for Skin Drug Delivery. Adv. Drug Deliv. Rev. 2011, 63, 470-491. [CrossRef]

45. de Souza, M.L.; dos Santos, W.M.; de Sousa, A.L.M.D.; de Albuquerque Wanderley Sales, V.; Nóbrega, F.P.; de Oliveira, M.V.G.; Rolim-Neto, P.J. Lipid Nanoparticles as a Skin Wound Healing Drug Delivery System: Discoveries and Advances. Curr. Pharm. Des. 2020, 26, 4536-4550. [CrossRef] [PubMed]

46. Tiwari, V.K. Burn Wound: How It Differs from Other Wounds. Indian J. Plast. Surg. 2012, 45, 364-373. [CrossRef]

47. Ali, M.; Jahromi, M.; Zangabad, P.S.; Moosavi, S.M.; Zangabad, K.S.; Ghamarypour, A.; Aref, A.R.; Hamblin, M.R.; Education, U.S.; Education, U.S. Nanomedicine and Advanced Technologies for Burns: Preventing Infection and Facilitating Wound Healing. Adv. Drug Deliv. Rev. 2018, 123, 33-64. [CrossRef]

48. Xu, H.L.; Chen, P.P.; ZhuGe, D.L.; Zhu, Q.Y.; Jin, B.H.; Shen, B.X.; Xiao, J.; Zhao, Y.Z. Liposomes with Silk Fibroin Hydrogel Core to Stabilize BFGF and Promote the Wound Healing of Mice with Deep Second-Degree Scald. Adv. Healthc. Mater. 2017, 6. [CrossRef] [PubMed]

49. Li, Z.; Liu, M.; Wang, H.; Du, S. Increased Cutaneous Wound Healing Effect of Biodegradable Liposomes Containing Madecassoside: Preparation Optimization, in Vitro Dermal Permeation, and in Vivo Bioevaluation. Int. J. Nanomed. 2016, 11, $2995-3007$. [CrossRef] [PubMed]

50. Alemdaroğlu, C.; Degim, Z.; Celebi, N.; Şengezer, M.; Alömeroglu, M.; Nacar, A.; Galili, U.; Değim, Z.; Çelebi, N.; Alemdaroğlu, C.; et al. Investigation of Epidermal Growth Factor Containing Liposome Formulation Effects on Burn Wound Healing. J. Biomed. Mater. Res. Part A 2008, 85, 271-283. [CrossRef]

51. Wasef, L.G.; Shaheen, H.M.; El-Sayed, Y.S.; Shalaby, T.I.A.; Samak, D.H.; Abd El-Hack, M.E.; Al-Owaimer, A.; Saadeldin, I.M.; El-mleeh, A.; Ba-Awadh, H.; et al. Effects of Silver Nanoparticles on Burn Wound Healing in a Mouse Model. Biol. Trace Elem. Res. 2020, 193, 456-465. [CrossRef]

52. Saporito, F.; Sandri, G.; Bonferoni, M.C.; Rossi, S.; Boselli, C.; Cornaglia, A.I.; Mannucci, B.; Grisoli, P.; Vigani, B.; Ferrari, F. Essential Oil-Loaded Lipid Nanoparticles for Wound Healing. Int. J. Nanomed. 2018, 13, 175-186. [CrossRef]

53. Leaper, D.J. Traumatic and Surgical Wounds. BMJ 2006, 332, 532-535. [CrossRef]

54. Goyal, R.; Macri, L.K.; Kaplan, H.M.; Kohn, J. Nanoparticles and Nanofibers for Topical Drug Delivery. J. Control. Release 2016, 240, 77-92. [CrossRef]

55. Arantes, V.T.; Faraco, A.A.G.; Ferreira, F.B.; Oliveira, C.A.; Martins-Santos, E.; Cassini-Vieira, P.; Barcelos, L.S.; Ferreira, L.A.M.; Goulart, G.A.C. Retinoic Acid-Loaded Solid Lipid Nanoparticles Surrounded by Chitosan Film Support Diabetic Wound Healing in in Vivo Study. Colloids Surf. B Biointerfaces 2020, 188, 110749. [CrossRef] [PubMed]

56. Sun, D.; Guo, S.; Yang, L.; Wang, Y.; Wei, X.; Song, S.; Yang, Y.; Gan, Y.; Wang, Z. Silicone Elastomer Gel Impregnated with 20(S)-Protopanaxadiol-Loaded Nanostructured Lipid Carriers for Ordered Diabetic Ulcer Recovery. Acta Pharmacol. Sin. 2020, 41, 119-128. [CrossRef]

57. Lee, H.J.; Jeong, M.; Na, Y.G.; Kim, S.J.; Lee, H.K.; Cho, C.W. An EGF- And Curcumin-Co-Encapsulated Nanostructured Lipid Carrier Accelerates Chronic-Wound Healing in Diabetic Rats. Molecules 2020, 25, 4610. [CrossRef] [PubMed]

58. Motawea, A.; Abd El-Gawad, A.E.G.H.; Borg, T.; Motawea, M.; Tarshoby, M. The Impact of Topical Phenytoin Loaded Nanostructured Lipid Carriers in Diabetic Foot Ulceration. Foot 2019, 40, 14-21. [CrossRef] [PubMed]

59. Kasiewicz, L.N.; Whitehead, K.A. Lipid Nanoparticles Silence Tumor Necrosis Factor $\alpha$ to Improve Wound Healing in Diabetic Mice. Bioeng. Transl. Med. 2019, 4, 75-82. [CrossRef]

60. Ghasemiyeh, P.; Mohammadi-Samani, S. Potential of Nanoparticles as Permeation Enhancers and Targeted Delivery Options for Skin: Advantages and Disadvantages. Drug Des. Dev. Ther. 2020, 14, 3271-3289. [CrossRef] [PubMed]

61. Chato-Astrain, J.; Chato-Astrain, I.; Sánchez-Porras, D.; García-García, Ó.D.; Bermejo-Casares, F.; Vairo, C.; Villar-Vidal, M.; Gainza, G.; Villullas, S.; Oruezabal, R.I.; et al. Generation of a Novel Human Dermal Substitute Functionalized with AntibioticLoaded Nanostructured Lipid Carriers (NLCs) with Antimicrobial Properties for Tissue Engineering. J. Nanobiotechnol. 2020, 18, 1-13. [CrossRef]

62. Gabriel, A.; Gupta, S.; Orgill, D.P. Challenges and Management of Surgical Site Occurrences. Plast. Reconstr. Surg. 2019, 143, 7S-10S. [CrossRef]

63. Naskar, A.; Kim, K.S. Recent Advances in Nanomaterial-Based Wound-Healing Therapeutics. Pharmaceutics 2020, 12 , 499. [CrossRef]

64. Choi, J.U.; Lee, S.W.; Pangeni, R.; Byun, Y.; Yoon, I.S.; Park, J.W. Preparation and in Vivo Evaluation of Cationic Elastic Liposomes Comprising Highly Skin-Permeable Growth Factors Combined with Hyaluronic Acid for Enhanced Diabetic Wound-Healing Therapy. Acta Biomater. 2017, 57, 197-215. [CrossRef]

65. Van Vuuren, S.F.; Suliman, S.; Viljoen, A.M. The Antimicrobial Activity of Four Commercial Essential Oils in Combination with Conventional Antimicrobials. Lett. Appl. Microbiol. 2009, 48, 440-446. [CrossRef] [PubMed] 
66. Grubbs, H.; Manna, B. Wound Physiology. In StatPearls; StatPearls Publishing: Treasure Island, FL, USA, 2020.

67. Tran, T.-N.T. Cutaneous Drug Delivery: An Update. J. Investig. Dermatol. Symp. Proc. 2013, 16, S67-S69. [CrossRef] [PubMed]

68. Liu, J.; Hu, G. Advances in Studies of Phospholipids as Carriers in Skin Topical Application. J. Nanjing Med. Univ. 2007, 21, 349-353. [CrossRef]

69. Manca, M.L.; Matricardi, P.; Cencetti, C.; Peris, J.E.; Melis, V.; Carbone, C.; Escribano, E.; Zaru, M.; Fadda, A.M.; Manconi, M. Combination of Argan Oil and Phospholipids for the Development of an Effective Liposome-like Formulation Able to Improve Skin Hydration and Allantoin Dermal Delivery. Int. J. Pharm. 2016, 5052, 204-211. [CrossRef] [PubMed]

70. Elsayed, M.M.A.; Abdallah, O.Y.; Naggar, V.F.; Khalafallah, N.M. Deformable Liposomes and Ethosomes: Mechanism of Enhanced Skin Delivery. Int. J. Pharm. 2006, 322, 60-66. [CrossRef] [PubMed]

71. Mbah, C.C.; Builders, P.F.; Attama, A.A. Nanovesicular Carriers as Alternative Drug Delivery Systems: Ethosomes in Focus. Expert Opin. Drug Deliv. 2014, 11, 45-59. [CrossRef]

72. Mortensen, L.J.; Oberdörster, G.; Pentland, A.P.; DeLouise, L.A. In Vivo Skin Penetration of Quantum Dot Nanoparticles in the Murine Model: The Effect of UVR. Nano Lett. 2008, 8, 2779-2787. [CrossRef] [PubMed]

73. Zhu, Y.; Choe, C.-S.; Ahlberg, S.; Meinke, M.C.; Alexiev, U.; Lademann, J.; Darvin, M.E. Penetration of Silver Nanoparticles into Porcine Skin Ex Vivo Using Fluorescence Lifetime Imaging Microscopy, Raman Microscopy, and Surface-Enhanced Raman Scattering Microscopy. J. Biomed. Opt. 2014, 20, 051006. [CrossRef] [PubMed]

74. Lademann, J.; Knorr, F.; Richter, H.; Blume-Peytavi, U.; Vogt, A.; Antoniou, C.; Sterry, W.; Patzelt, A. Hair Follicles-An Efficient Storage and Penetration Pathway for Topically Applied Substances: Summary of Recent Results Obtained at the Center of Experimental and Applied Cutaneous Physiology, Charité-Universitätsmedizin Berlin, Germany. Skin Pharmacol. Physiol. 2008, 21, 150-155. [CrossRef] [PubMed]

75. Papakostas, D.; Rancan, F.; Sterry, W.; Blume-Peytavi, U.; Vogt, A. Nanoparticles in Dermatology. Arch. Dermatol. Res. 2011, 303, 533-550. [CrossRef]

76. Teichmann, A.; Jacobi, U.; Ossadnik, M.; Richter, H.; Koch, S.; Sterry, W.; Lademann, J. Differential Stripping: Determination of the Amount of Topically Applied Substances Penetrated into the Hair Follicles. J. Investig. Dermatol. 2005, 125, 264-269. [CrossRef]

77. Benson, H.A.E.; Grice, J.E.; Mohammed, Y.; Namjoshi, S.; Roberts, M.S. Topical and Transdermal Drug Delivery: From Simple Potions to Smart Technologies. Curr. Drug Deliv. 2019, 16, 444-460. [CrossRef]

78. Larese Filon, F.; Mauro, M.; Adami, G.; Bovenzi, M.; Crosera, M. Nanoparticles Skin Absorption: New Aspects for a Safety Profile Evaluation. Regul. Toxicol. Pharmacol. 2015, 72, 310-322. [CrossRef]

79. Brown, M.B.; Martin, G.P.; Jones, S.A.; Akomeah, F.K. Dermal and Transdermal Drug Delivery Systems: Current and Future Prospects. Drug Deliv. J. Deliv. Target. Ther. Agents 2006, 13, 175-187. [CrossRef]

80. Palmer, B.C.; DeLouise, L.A. Nanoparticle-Enabled Transdermal Drug Delivery Systems for Enhanced Dose Control and Tissue Targeting. Molecules 2016, 21, 1719. [CrossRef]

81. Risaliti, L.; Kehagia, A.; Daoultzi, E.; Lazari, D.; Bergonzi, M.C.; Vergkizi-Nikolakaki, S.; Hadjipavlou-Litina, D.; Bilia, A.R. Liposomes Loaded with Salvia Triloba and Rosmarinus Officinalis Essential Oils: In Vitro Assessment of Antioxidant, Antiinflammatory and Antibacterial Activities. J. Drug Deliv. Sci. Technol. 2019, 51, 493-498. [CrossRef]

82. Razavi, S.; Partoazar, A.; Takzaree, N.; Fasihi-Ramandi, M.; Bahador, A.; Darvishi, M.H. Silver Sulfadiazine Nanoethogel for Burn Healing: Characterization and Investigation of Its in Vivo Effects. Nanomedicine 2018, 13, 1319-1331. [CrossRef]

83. Kakkar, V.; Kaur, I.P.; Kaur, A.P.; Saini, K.; Singh, K.K. Topical Delivery of Tetrahydrocurcumin Lipid Nanoparticles Effectively Inhibits Skin Inflammation: In Vitro and in Vivo Study. Drug Dev. Ind. Pharm. 2018, 44, 1701-1712. [CrossRef] [PubMed]

84. Gad, H.A.; Abd El-Rahman, F.A.A.; Hamdy, G.M. Chamomile Oil Loaded Solid Lipid Nanoparticles: A Naturally Formulated Remedy to Enhance the Wound Healing. J. Drug Deliv. Sci. Technol. 2019, 50, 329-338. [CrossRef]

85. Fumakia, M.; Ho, E.A. Nanoparticles Encapsulated with LL37 and Serpin A1 Promotes Wound Healing and Synergistically Enhances Antibacterial Activity. Mol. Pharm. 2016, 13, 2318-2331. [CrossRef] [PubMed]

86. Garcia-Orue, I.; Gainza, G.; Girbau, C.; Alonso, R.; Aguirre, J.J.; Pedraz, J.L.; Igartua, M.; Hernandez, R.M. LL37 Loaded Nanostructured Lipid Carriers (NLC): A New Strategy for the Topical Treatment of Chronic Wounds. Eur. J. Pharm. Biopharm. 2016, 108, 310-316. [CrossRef]

87. Ghodrati, M.; Farahpour, M.R.; Hamishehkar, H. Encapsulation of Peppermint Essential Oil in Nanostructured Lipid Carriers: In-Vitro Antibacterial Activity and Accelerative Effect on Infected Wound Healing. Colloids Surf. A Physicochem. Eng. Asp. 2019, 564, 161-169. [CrossRef]

88. Bangham, A.D.; Haydon, D.A. Ultrastructure of Membranes: Bimolecular Organization. Br. Med. Bull. 1968, 24, 124-126. [CrossRef] [PubMed]

89. Honeywell-Nguyen, P.L.; Bouwstra, J.A. Vesicles as a Tool for Transdermal and Dermal Delivery. Drug Discov. Today Technol. 2005, 2, 67-74. [CrossRef]

90. Ramanunny, A.K.; Wadhwa, S.; Gulati, M.; Singh, S.K.; Kapoor, B.; Dureja, H.; Chellappan, D.K.; Anand, K.; Dua, K.; Khursheed, R.; et al. Nanocarriers for Treatment of Dermatological Diseases: Principle, Perspective and Practices. Eur. J. Pharmacol. 2021, 890, 173691. [CrossRef]

91. Yadav, A.V.; Murthy, M.S.; Shete, A.S.; Sakhare, S. Stability Aspects of Liposomes. Indian J. Pharm. Educ. Res. 2011, 45, 402-413.

92. Payton, N.M.; Wempe, M.F.; Xu, Y.; Anchordoquy, T.J. Long-Term Storage of Lyophilized Liposomal Formulations. J. Pharm. Sci. 2014, 103, 3869-3878. [CrossRef] [PubMed] 
93. Kan, P.; Tsao, C.-W.; Wang, A.-J.; Su, W.-C.; Liang, H.-F. A Liposomal Formulation Able to Incorporate a High Content of Paclitaxel and Exert Promising Anticancer Effect. J. Drug Deliv. 2011, 2011, 1-9. [CrossRef]

94. Pandey, H.; Rani, R.; Agarwal, V. Liposome and Their Applications in Cancer Therapy. Braz. Arch. Biol. Technol. 2016, 59. [CrossRef]

95. Akbarzadeh, A.; Rezaei-Sadabady, R.; Davaran, S.; Joo, S.W.; Zarghami, N.; Hanifehpour, Y.; Samiei, M.; Kouhi, M.; Nejati-Koshki, K. Liposome: Classification, Preparation, and Applications. Nanoscale Res. Lett. 2013, 8, 102. [CrossRef]

96. Hasanovic, A.; Hollick, C.; Fischinger, K.; Valenta, C. Improvement in Physicochemical Parameters of DPPC Liposomes and Increase in Skin Permeation of Aciclovir and Minoxidil by the Addition of Cationic Polymers. Eur. J. Pharm. Biopharm. 2010, 75, 148-153. [CrossRef] [PubMed]

97. Rabbani, P.S.; Zhou, A.; Borab, Z.M.; Frezzo, J.A.; Srivastava, N.; More, H.T.; Rifkin, W.J.; David, J.A.; Berens, S.J.; Chen, R.; et al. Novel Lipoproteoplex Delivers Keap1 SiRNA Based Gene Therapy to Accelerate Diabetic Wound Healing. Biomaterials 2017, 132, 1-15. [CrossRef] [PubMed]

98. Li, D.; Wang, A.; Liu, X.; Meisgen, F.; Grünler, J.; Botusan, I.R.; Narayanan, S.; Erikci, E.; Li, X.; Blomqvist, L.; et al. MicroRNA-132 Enhances Transition from Inflammation to Proliferation during Wound Healing. J. Clin. Investig. 2015, 125, 3008-3026. [CrossRef] [PubMed]

99. Li, X.; Li, D.; Wang, A.; Chu, T.; Lohcharoenkal, W.; Zheng, X.; Grünler, J.; Narayanan, S.; Eliasson, S.; Herter, E.K.; et al. MicroRNA-132 with Therapeutic Potential in Chronic Wounds. J. Investig. Dermatol. 2017, 137, 2630-2638. [CrossRef]

100. Wang, J.; Zhang, Q.; Wan, R.; Mo, Y.; Li, M.; Tseng, M.T.; Chien, S. Intracellular Adenosine Triphosphate Delivery Enhanced Skin Wound Healing in Rabbits. Ann. Plast. Surg. 2009, 62, 180-186. [CrossRef]

101. Roesken, F.; Uhl, E.; Curri, S.B.; Menger, M.D.; Messmer, K. Acceleration of Wound Healing by Topical Drug Delivery via Liposomes. Langenbeck's Arch. Surg. 2000, 385, 42-49. [CrossRef]

102. Das, S.; Majid, M.; Baker, A.B. Syndecan-4 Enhances PDGF-BB Activity in Diabetic Wound Healing. Acta Biomater. 2016, 42, 56-65. [CrossRef]

103. Değim, Z.; Çelebi, N.; Alemdaroğlu, C.; Deveci, M.; Öztürk, S.; Özoğul, C. Evaluation of Chitosan Gel Containing LiposomeLoaded Epidermal Growth Factor on Burn Wound Healing. Int. Wound J. 2011, 8, 343-354. [CrossRef]

104. Usach, I.; Margarucci, E.; Manca, M.L.; Caddeo, C.; Aroffu, M.; Petretto, G.L.; Manconi, M.; Peris, J.E. Comparison between Citral and Pompia Essential Oil Loaded in Phospholipid Vesicles for the Treatment of Skin and Mucosal Infections. Nanomaterials 2020, 10, 286. [CrossRef] [PubMed]

105. Wang, H.; Liu, M.; Du, S. Optimization of Madecassoside Liposomes Using Response Surface Methodology and Evaluation of Its Stability. Int. J. Pharm. 2014, 473, 280-285. [CrossRef]

106. Mitragotri, S.; Burke, P.A.; Langer, R. Overcoming the Challenges in Administering Biopharmaceuticals: Formulation and Delivery Strategies. Nat. Rev. Drug Discov. 2014, 13, 655-672. [CrossRef] [PubMed]

107. Wang, W.; Lu, K.J.; Yu, C.H.; Huang, Q.L.; Du, Y.Z. Nano-Drug Delivery Systems in Wound Treatment and Skin Regeneration. J. Nanobiotechnol. 2019, 17, 1-15. [CrossRef] [PubMed]

108. Jadupati, M.; Kumar, N.A. Transferosome: An opportunistic carrier for transdermal drug delivery system. Int. Res. J. Pharm. 2012, 3, 35-38.

109. Elsayed, M.M.A.; Abdallah, O.Y.; Naggar, V.F.; Khalafallah, N.M. Lipid Vesicles for Skin Delivery of Drugs: Reviewing Three Decades of Research. Int. J. Pharm. 2007, 332, 1-16. [CrossRef]

110. Jain, S.; Jain, P.; Umamaheshwari, R.B.; Jain, N.K. Transfersomes-A Novel Vesicular Carrier for Enhanced Transdermal Delivery: Development, Characterization, and Performance Evaluation. Drug Dev. Ind. Pharm. 2003, 29, 1013-1026. [CrossRef]

111. Opatha, S.A.T.; Titapiwatanakun, V.; Chutoprapat, R. Transfersomes: A Promising Nanoencapsulation Technique for Transdermal Drug Delivery. Pharmaceutics 2020, 12, 855. [CrossRef]

112. Shamma, R.N.; Elsayed, I. Transfersomal Lyophilized Gel of Buspirone HCl: Formulation, Evaluation and Statistical Optimization. J. Liposome Res. 2013, 23, 244-254. [CrossRef]

113. Hussain, A.; Singh, S.; Sharma, D.; Webster, T.J.; Shafaat, K.; Faruk, A. Elastic Liposomes as Novel Carriers: Recent Advances in Drug Delivery. Int. J. Nanomed. 2017, 12, 5087-5108. [CrossRef] [PubMed]

114. Benson, H.A.E. Transfersomes for Transdermal Drug Delivery. Expert Opin. Drug Deliv. 2006, 3, 727-737. [CrossRef]

115. Kulkarni, R.; Yadav, J.D.; Vaidya, K.A.; Gandhi, P.P. Transferosomes: An Emerging Tool for Transdermal Drug Delivery. Int. J. Pharm. Sci. Res. 2011, 2, 735-741.

116. Surini, S.; Leonyza, A.; Suh, C.W. Formulation and in Vitro Penetration Study of Recombinant Human Epidermal Growth Factor-Loaded Transfersomal Emulgel. Adv. Pharm. Bull. 2020, 10, 586-594. [CrossRef] [PubMed]

117. Yang, C.H.; Huang, Y.B.; Wu, P.C.; Tsai, Y.H. The Evaluation of Stability of Recombinant Human Epidermal Growth Factor in Burn-Injured Pigs. Process Biochem. 2005, 40, 1661-1665. [CrossRef]

118. El-Gizawy, S.A.; Nouh, A.; Saber, S.; Kira, A.Y. Deferoxamine-Loaded Transfersomes Accelerates Healing of Pressure Ulcers in Streptozotocin-Induced Diabetic Rats. J. Drug Deliv. Sci. Technol. 2020, 58, 101732. [CrossRef]

119. Badhe, K.P.; Kundu, P.; Badhe, K.P.; Dube, R.K. Introduction to Ethosome as a Novel Drug Carrier System. J. Pharm. Res. 2012, 55, 5224-5227.

120. Pingale, P. Ethosomes-Newer Trend in Transdermal Drug Delivery: A Review. Int. J. Pharma Res. Health Sci. 2018, 6, 2586-2590. [CrossRef] 
121. Iqbal, B.; Ali, J.; Baboota, S. Recent Advances and Development in Epidermal and Dermal Drug Deposition Enhancement Technology. Int. J. Dermatol. 2018, 57, 646-660. [CrossRef] [PubMed]

122. Bhalaria, M.K.; Naik, S.; Misra, A.N. Ethosomes: A Novel Delivery System for Antifungal Drugs in the Treatment of Topical Fungal Diseases. Indian J. Exp. Biol. 2009, 47, 368-375.

123. Dubey, V.; Mishra, D.; Dutta, T.; Nahar, M.; Saraf, D.K.; Jain, N.K. Dermal and Transdermal Delivery of an Anti-Psoriatic Agent via Ethanolic Liposomes. J. Control. Release 2007, 123, 148-154. [CrossRef] [PubMed]

124. Verma, P.; Pathak, K. Therapeutic and Cosmeceutical Potential of Ethosomes: An Overview. J. Adv. Pharm. Technol. Res. 2010, 1, 274-282. [CrossRef]

125. Pandey, V.; Golhani, D.; Shukla, R. Ethosomes: Versatile Vesicular Carriers for Efficient Transdermal Delivery of Therapeutic Agents. Drug Deliv. 2015, 22, 988-1002. [CrossRef] [PubMed]

126. Debnath, A.; Sharma, S.; Sharma, P.K. Potential Transdermal Delivery of Herbal Drug Via Ethosomal System for the Treatment of Various. World J. Pharm. Res. 2020, 9, 250-267. [CrossRef]

127. Cortesi, R.; Ravani, L.; Zaid, A.N.; Menegatti, E.; Romagnoli, R.; Drechsler, M.; Esposito, E.; Cortesi, R. Ethosomes for the Delivery of Anti-HSV-1 Molecules: Preparation, Characterization and in Vitro Activity. Pharmazie 2010, 65, 743-749. [CrossRef] [PubMed]

128. Partoazar, A.; Kianvash, N.; Darvishi, M.H.; Nasoohi, S.; Rezayat, S.M.; Bahador, A. Ethosomal Curcumin Promoted Wound Healing and Reduced Bacterial Flora in Second Degree Burn in Rat. Drug Res. 2016, 66, 660-665. [CrossRef]

129. Zhao, Y.Z.; Lu, C.T.; Zhang, Y.; Xiao, J.; Zhao, Y.P.; Tian, J.L.; Xu, Y.Y.; Feng, Z.G.; Xu, C.Y. Selection of High Efficient Transdermal Lipid Vesicle for Curcumin Skin Delivery. Int. J. Pharm. 2013, 454, 302-309. [CrossRef] [PubMed]

130. Jain, S.; Patel, N.; Madan, P.; Lin, S. Formulation and Rheological Evaluation of Ethosome-Loaded Carbopol Hydrogel for Transdermal Application. Drug Dev. Ind. Pharm. 2016, 42, 1315-1324. [CrossRef]

131. Scheau, C.; Badarau, I.A.; Mihai, L.G.; Scheau, A.E.; Costache, D.O.; Constantin, C.; Calina, D.; Caruntu, C.; Costache, R.S.; Caruntu, A. Cannabinoids in the Pathophysiology of Skin Inflammation. Molecules 2020, 25, 652. [CrossRef]

132. Ilie, M.A.; Caruntu, C.; Lixandru, D.; Tampa, M.; Georgescu, S.R.; Constantin, M.M.; Constantin, C.; Neagu, M.; Zurac, S.A.; Boda, D. In Vivo Confocal Laser Scanning Microscopy Imaging of Skin Inflammation: Clinical Applications and Research Directions (Review). Exp. Ther. Med. 2019, 17, 1004-1011. [CrossRef]

133. Neagu, M.; Constantin, C.; Caruntu, C.; Dumitru, C.; Surcel, M.; Zurac, S. Inflammation: A Key Process in Skin Tumorigenesis (Review). Oncol. Lett. 2019, 17, 4068-4084. [CrossRef]

134. Kazemi, M.; Mombeiny, R.; Tavakol, S.; Keyhanvar, P.; Mousavizadeh, K. Combination Therapy of Nanoethosomal Piroxicam Formulation along with Iontophoresis as an Anti-Inflammatory Transdermal Delivery System for Wound Healing. Int. Wound J. 2019, 16, 1144-1152. [CrossRef]

135. Fu, X.; Shi, Y.; Wang, H.; Zhao, X.; Sun, Q.; Huang, Y.; Qi, T.; Lin, G. Ethosomal Gel for Improving Transdermal Delivery of Thymosin $\beta-4$. Int. J. Nanomed. 2019, 14, 9275-9284. [CrossRef]

136. Wissing, S.A.; Müller, R.H. The Influence of the Crystallinity of Lipid Nanoparticles on Their Occlusive Properties. Int. J. Pharm. 2002, 242, 377-379. [CrossRef]

137. Khalil, M.H.; Marcelletti, J.F.; Katz, L.R.; Katz, D.H.; Pope, L.E. Topical Application of Docosanol-or Stearic Acid-Containing Creams Reduces Severity of Phenol Burn Wounds in Mice. Contact Dermat. 2000, 43, 79-81. [CrossRef] [PubMed]

138. Pardeike, J.; Hommoss, A.; Müller, R.H. Lipid Nanoparticles (SLN, NLC) in Cosmetic and Pharmaceutical Dermal Products. Int. J. Pharm. 2009, 366, 170-184. [CrossRef] [PubMed]

139. Mukherjee, S.; Ray, S.; Thakur, R.S. Solid Lipid Nanoparticles: A Modern Formulation Approach in Drug Delivery System. Indian J. Pharm. Sci. 2009, 71, 349-358. [CrossRef]

140. Daneshmand, S.; Golmohammadzadeh, S.; Jaafari, M.R.; Movaffagh, J.; Rezaee, M.; Sahebkar, A.; Malaekeh-Nikouei, B. Encapsulation Challenges, the Substantial Issue in Solid Lipid Nanoparticles Characterization. J. Cell. Biochem. 2018, 119, 4251-4264. [CrossRef] [PubMed]

141. Musicanti, C.; Gasco, P. Solid Lipid Nanoparticles-SLN. In Encyclopedia of Nanotechnology; Springer: Dordrecht, The Netherlands, 2012; pp. 2471-2487. [CrossRef]

142. Mehanna, M.M.; Mneimneh, A.T. Formulation and Applications of Lipid-Based Nanovehicles: Spotlight on Self-Emulsifying Systems. Adv. Pharm. Bull. 2021, 11, 56-67. [CrossRef] [PubMed]

143. Howard, M.D.; Lu, X.; Jay, M.; Dziubla, T.D. Optimization of the Lyophilization Process for Long-Term Stability of Solidlipid Nanoparticles. Drug Dev. Ind. Pharm. 2012, 38, 1270-1279. [CrossRef]

144. Dingler, A.; Gohla, S. Production of Solid Lipid Nanoparticles (SLN): Scaling up Feasibilities. J. Microencapsul. 2002, 19, 11-16. [CrossRef]

145. Patel, K.K.; Surekha, D.B.; Tripathi, M.; Anjum, M.M.; Muthu, M.S.; Tilak, R.; Agrawal, A.K.; Singh, S. Antibiofilm Potential of Silver Sulfadiazine-Loaded Nanoparticle Formulations: A Study on the Effect of DNase-I on Microbial Biofilm and Wound Healing Activity. Mol. Pharm. 2019, 16, 3916-3925. [CrossRef] [PubMed]

146. Esposito, E.; Pecorelli, A.; Sguizzato, M.; Drechsler, M.; Mariani, P.; Carducci, F.; Cervellati, F.; Nastruzzi, C.; Cortesi, R.; Valacchi, G. Production and Characterization of Nanoparticle Based Hyaluronate Gel Containing Retinyl Palmitate for Wound Healing. Curr. Drug Deliv. 2018, 15, 1172-1182. [CrossRef] [PubMed] 
147. Moglad, H.E.; Fatima, F.; Muqtader, A.M.; Devanathad, V.; Khalid Anw, M.; Aldawsa, M. Development of Topical Antibacterial Gel Loaded with Cefadroxil Solid Lipid Nanoparticles: In Vivo Wound Healing Activity and Epithelialization Study. Int. J. Pharmacol. 2020, 16, 298-309. [CrossRef]

148. Poon, V.K.M.; Burd, A. In Vitro Cytotoxity of Silver: Implication for Clinical Wound Care. Burns 2004, 30, 140-147. [CrossRef]

149. Ghaffari, S.; Alihosseini, F.; Rezayat Sorkhabadi, S.M.; Bidgoli, S.A.; Mousavi, S.E.; Haghighat, S.; Nasab, A.A.; Kianvash, N. Nanotechnology in Wound Healing; Semisolid Dosage Forms Containing Curcumin-Ampicillin Solid Lipid Nanoparticles, in-Vitro, Ex-Vivo and in-Vivo Characteristics. Adv. Pharm. Bull. 2018, 8, 395-400. [CrossRef]

150. Puri, D.; Mishra, A.; Singh, A.P.; Gaur, P.K.; Singh, M.; Yasir, M. Formulation Development of Topical Preparation Containing Nanoparticles of Povidone-Iodine for Wound Healing. Assay Drug Dev. Technol. 2021, 19, 115-123. [CrossRef]

151. Küchler, S.; Wolf, N.B.; Heilmann, S.; Weindl, G.; Helfmann, J.; Yahya, M.M.; Stein, C.; Schäfer-Korting, M. 3D-Wound Healing Model: Influence of Morphine and Solid Lipid Nanoparticles. J. Biotechnol. 2010, 148, 24-30. [CrossRef]

152. Shrikhande, G.; Khaodhiar, L.; Scali, S.; Lima, C.; Hubbard, M.; Dudley, K.; Ganda, O.; Ferran, C.; Veves, A. Valsartan Improves Resting Skin Blood Flow in Type 2 Diabetic Patients and Reduces Poly(Adenosine Diphosphate-Ribose) Polymerase Activation. J. Vasc. Surg. 2006, 43, 760-770. [CrossRef]

153. Abadir, P.; Hosseini, S.; Faghih, M.; Ansari, A.; Lay, F.; Smith, B.; Beselman, A.; Vuong, D.; Berger, A.; Tian, J.; et al. Topical Reformulation of Valsartan for Treatment of Chronic Diabetic Wounds. J. Investig. Dermatol. 2018, 138, 434-443. [CrossRef]

154. El-Salamouni, N.S.; Gowayed, M.A.; Seiffein, N.L.; Abdel- Moneim, R.A.; Kamel, M.A.; Labib, G.S. Valsartan Solid Lipid Nanoparticles Integrated Hydrogel: A Challenging Repurposed Use in the Treatment of Diabetic Foot Ulcer, in-Vitro/in-Vivo Experimental Study. Int. J. Pharm. 2021, 592, 120091. [CrossRef]

155. Jain, P.; Rahi, P.; Pandey, V.; Asati, S.; Soni, V. Nanostructure Lipid Carriers: A Modish Contrivance to Overcome the Ultraviolet Effects. Egypt. J. Basic Appl. Sci. 2017, 4, 89-100. [CrossRef]

156. Khan, A.A.; Mudassir, J.; Akhtar, S.; Murugaiyah, V.; Darwis, Y. Freeze-Dried Lopinavir-Loaded Nanostructured Lipid Carriers for Enhanced Cellular Uptake and Bioavailability: Statistical Optimization, in Vitro and in Vivo Evaluations. Pharmaceutics 2019, 11, 97. [CrossRef] [PubMed]

157. Karakash, I.; Vasileska, J.; Shalabalija, D.; Mihailova, L.; Dodov, G.; Raicki, R.S.; Simonoska Crcarevska, M. Freeze-Drying of Nanostructured Lipid Carriers Loaded with Salvia off. Extract for Alzheimer's Disease Treatment. Maced. Pharm. Bull. 2020, 66, 219-220. [CrossRef]

158. Xia, Q.; Kong, R. Freeze-Drying and Characterization of Vitamin A Palmitate-Loaded Nanostructured Lipid Carriers (NLC). Mater. Sci. Forum 2011, 694, 365-369. [CrossRef]

159. Subramaniam, B.; Siddik, Z.H.; Nagoor, N.H. Optimization of Nanostructured Lipid Carriers: Understanding the Types, Designs, and Parameters in the Process of Formulations. J. Nanopart. Res. 2020, 22, 1-29. [CrossRef]

160. Mishra, S.; Kesharwani, R.; Tiwari, A.K.; Patel, D.K. Improvement of Drug Penetration through the Skin by Using Nanostructured Lipid Carriers ( NLC ). Int. J. Pharm. Pharm. Res. 2016, 6, 1-16.

161. Haider, M.; Abdin, S.M.; Kamal, L.; Orive, G. Nanostructured Lipid Carriers for Delivery of Chemotherapeutics: A Review. Pharmaceutics 2020, 12, 288. [CrossRef]

162. Naseri, N.; Valizadeh, H.; Zakeri-Milani, P. Solid Lipid Nanoparticles and Nanostructured Lipid Carriers: Structure Preparation and Application. Adv. Pharm. Bull. 2015, 5, 305-313. [CrossRef]

163. Gainza, G.; Pastor, M.; Aguirre, J.J.; Villullas, S.; Pedraz, J.L.; Hernandez, R.M.; Igartua, M. A Novel Strategy for the Treatment of Chronic Wounds Based on the Topical Administration of RhEGF-Loaded Lipid Nanoparticles: In Vitro Bioactivity and in Vivo Effectiveness in Healing-Impaired Db/Db Mice. J. Control. Release 2014, 185, 51-61. [CrossRef] [PubMed]

164. Khezri, K.; Farahpour, M.R.; Mounesi Rad, S. Efficacy of Mentha Pulegium Essential Oil Encapsulated into Nanostructured Lipid Carriers as an in Vitro Antibacterial and Infected Wound Healing Agent. Colloids Surf. A Physicochem. Eng. Asp. 2020, 589, 124414. [CrossRef]

165. Nicolae, I.; Daniela Ene, C.; Georgescu, S.R.; Tampa, M.; Matei, C.; Ceausu, E. Effects of UV Radiation and Oxidative DNA Adduct 8-Hydroxy-2'-Deoxiguanosine on the Skin Diseases. Rev. Chim Buchar. 2014, 65, 1036-1041.

166. Tampa, M.; Sarbu, M.-I.; Mitran, M.-I.; Mitran, C.-I.; Matei, C.; Georgescu, S.-R. The Pathophysiological Mechanisms and the Quest for Biomarkers in Psoriasis, a Stress-Related Skin Disease. Dis. Markers 2018, 2018, 5823684. [CrossRef]

167. Tampa, M.; Nicolae, I.; Ene, C.D.; Sarbu, I.; Matei, C.; Georgescu, S.R. Vitamin C and Thiobarbituric Acid Reactive Substances (TBARS) in Psoriasis Vulgaris Related to Psoriasis Area Severity Index (PASI). Rev. Chim. 2017, 68, 43-47. [CrossRef]

168. Georgescu, S.; Daniela, C.; Tampa, M.; Matei, C.; Benea, V.; Nicolae, I. Oxidative Stress-Related Markers and Alopecia Areata Through Latex Turbidimetric Immunoassay Method. Mater. Plast. 2016, 53, 522-526.

169. Căruntu, C.; Negrei, C.; Boda, D.; Constantin, C.; Căruntu, A.; Neagu, M. Biotechnological Advances for Diagnosis of Peripheral Diabetic Neuropathy. Rom. Biotechnol. Lett. 2014, 19, 9846-9858.

170. Krausz, A.E.; Adler, B.L.; Cabral, V.; Navati, M.; Doerner, J.; Charafeddine, R.A.; Chandra, D.; Liang, H.; Gunther, L.; Clendaniel, A.; et al. Curcumin-Encapsulated Nanoparticles as Innovative Antimicrobial and Wound Healing Agent. Nanomed. Nanotechnol. Biol. Med. 2015, 11, 195-206. [CrossRef] [PubMed]

171. Duvnjak Romić, M.; Špoljarić, D.; Šegvić Klarić, M.; Cetina-Čižmek, B.; Filipović-Grčić, J.; Hafner, A. Melatonin Loaded Lipid Enriched Chitosan Microspheres-Hybrid Dressing for Moderate Exuding Wounds. J. Drug Deliv. Sci. Technol. 2019, 52, 431-439. [CrossRef] 
172. Romić, M.D.; Klarić, M.Š.; Lovrić, J.; Pepić, I.; Cetina-Čižmek, B.; Filipović-Grčić, J.; Hafner, A. Melatonin-Loaded Chitosan/Pluronic ${ }^{\circledR}$ F127 Microspheres as in Situ Forming Hydrogel: An Innovative Antimicrobial Wound Dressing. Eur. J. Pharm. Biopharm. 2016, 107, 67-79. [CrossRef]

173. Pivetta, T.P.; Simões, S.; Araújo, M.M.; Carvalho, T.; Arruda, C.; Marcato, P.D. Development of Nanoparticles from Natural Lipids for Topical Delivery of Thymol: Investigation of Its Anti-Inflammatory Properties. Colloids Surf. B Biointerfaces 2018, 164, 281-290. [CrossRef]

174. Bleasdale, B.; Finnegan, S.; Murray, K.; Kelly, S.; Percival, S.L. The Use of Silicone Adhesives for Scar Reduction. Adv. Wound Care 2015, 4, 422-430. [CrossRef] [PubMed]

175. Hoy, S.M. Patisiran: First Global Approval. Drugs 2018, 78, 1625-1631. [CrossRef] [PubMed]

176. Herter, E.K.; Xu Landén, N. Non-Coding RNAs: New Players in Skin Wound Healing. Adv. Wound Care 2017, 6, 93-107. [CrossRef] [PubMed]

177. Ashton, S.; Song, Y.H.; Nolan, J.; Cadogan, E.; Murray, J.; Odedra, R.; Foster, J.; Hall, P.A.; Low, S.; Taylor, P.; et al. Aurora Kinase Inhibitor Nanoparticles Target Tumors with Favorable Therapeutic Index in Vivo. Sci. Transl. Med. 2016, 8. [CrossRef] [PubMed]

178. Liang, X.; Ma, L.; Long, X.; Wang, X. LncRNA Expression Profiles and Validation in Keloid and Normal Skin Tissue. Int. J. Oncol. 2015, 47, 1829-1838. [CrossRef] [PubMed]

179. Banerjee, J.; Chan, Y.C.; Sen, C.K. MicroRNAs in Skin and Wound Healing. Physiol. Genom. 2011, 43, 543-556. [CrossRef] [PubMed]

180. Kato, M.; Zhang, J.; Wang, M.; Lanting, L.; Yuan, H.; Rossi, J.J.; Natarajan, R. MicroRNA-192 in Diabetic Kidney Glomeruli and Its Function in TGF- $\beta$-Induced Collagen Expression via Inhibition of E-Box Repressors. Proc. Natl. Acad. Sci. USA 2007, 104, 3432-3437. [CrossRef] [PubMed]

181. Mulholland, E.J.; Dunne, N.; McCarthy, H.O. MicroRNA as Therapeutic Targets for Chronic Wound Healing. Mol. Ther. Nucleic Acids 2017, 8, 46-55. [CrossRef]

182. Mao, Z.; Zhou, X.; Gao, C. Influence of Structure and Properties of Colloidal Biomaterials on Cellular Uptake and Cell Functions. Biomater. Sci. 2013, 2013, 896-911. [CrossRef]

183. Ghatak, S.; Li, J.; Chan, Y.C.; Gnyawali, S.C.; Steen, E.; Yung, B.C.; Khanna, S.; Roy, S.; Lee, R.J.; Sen, C.K. AntihypoxamiR Functionalized Gramicidin Lipid Nanoparticles Rescue against Ischemic Memory Improving Cutaneous Wound Healing. Nanomed. Nanotechnol. Biol. Med. 2016, 12, 1827-1831. [CrossRef]

184. Li, J.; Ghatak, S.; El Masry, M.S.; Das, A.; Liu, Y.; Roy, S.; Lee, R.J.; Sen, C.K. Topical Lyophilized Targeted Lipid Nanoparticles in the Restoration of Skin Barrier Function Following Burn Wound. Mol. Ther. 2018, 26, 2178-2188. [CrossRef]

185. Saleh, B.; Dhaliwal, H.K.; Portillo-Lara, R.; Shirzaei Sani, E.; Abdi, R.; Amiji, M.M.; Annabi, N. Local Immunomodulation Using an Adhesive Hydrogel Loaded with MiRNA-Laden Nanoparticles Promotes Wound Healing. Small 2019, 15, 1-15. [CrossRef]

186. Tezgel, Ö.; DiStasio, N.; Laghezza-Masci, V.; Taddei, A.R.; Szarpak-Jankowska, A.; Auzély-Velty, R.; Navarro, F.P.; Texier, I. Collagen Scaffold-Mediated Delivery of NLC/SiRNA as Wound Healing Materials. J. Drug Deliv. Sci. Technol. 2020, 55, 101421. [CrossRef]

187. Randeria, P.S.; Seeger, M.A.; Wang, X.Q.; Wilson, H.; Shipp, D.; Mirkin, C.A.; Paller, A.S. SiRNA-Based Spherical Nucleic Acids Reverse Impaired Wound Healing in Diabetic Mice by Ganglioside GM3 Synthase Knockdown. Proc. Natl. Acad. Sci. USA 2015, 112, 5573-5578. [CrossRef] [PubMed]

188. Hadinoto, K.; Sundaresan, A.; Cheow, W.S. Lipid-Polymer Hybrid Nanoparticles as a New Generation Therapeutic Delivery Platform: A Review. Eur. J. Pharm. Biopharm. 2013, 85, 427-443. [CrossRef]

189. Zhao, P.; Wang, H.; Yu, M.; Liao, Z.; Wang, X.; Zhang, F.; Ji, W.; Wu, B.; Han, J.; Zhang, H.; et al. Paclitaxel Loaded Folic Acid Targeted Nanoparticles of Mixed Lipid-Shell and Polymer-Core: In Vitro and in Vivo Evaluation. Eur. J. Pharm. Biopharm. 2012, 81, 248-256. [CrossRef] [PubMed]

190. Hu, C.M.J.; Zhang, L.; Aryal, S.; Cheung, C.; Fang, R.H.; Zhang, L. Erythrocyte Membrane-Camouflaged Polymeric Nanoparticles as a Biomimetic Delivery Platform. Proc. Natl. Acad. Sci. USA 2011, 108, 10980-10985. [CrossRef] [PubMed]

191. Chan, J.M.; Rhee, J.W.; Drum, C.L.; Bronson, R.T.; Golomb, G.; Langer, R.; Farokhzad, O.C. In Vivo Prevention of Arterial Restenosis with Paclitaxel-Encapsulated Targeted Lipid-Polymeric Nanoparticles. Proc. Natl. Acad. Sci. USA 2011, 108, 19347-19352. [CrossRef]

192. Desai, P.R.; Marepally, S.; Patel, A.R.; Voshavar, C.; Chaudhuri, A.; Singh, M. Topical Delivery of Anti-TNF $\alpha$ SiRNA and Capsaicin via Novel Lipid-Polymer Hybrid Nanoparticles Efficiently Inhibits Skin Inflammation in Vivo. J. Control. Release 2013, 170, 51-63. [CrossRef] [PubMed]

193. Thakur, K.; Sharma, G.; Singh, B.; Chhibber, S.; Katare, O.P. Nano-Engineered Lipid-Polymer Hybrid Nanoparticles of Fusidic Acid: An Investigative Study on Dermatokinetics Profile and MRSA-Infected Burn Wound Model. Drug Deliv. Transl. Res. 2019, 9 , 748-763. [CrossRef] [PubMed]

194. Thakur, K.; Sharma, G.; Singh, B.; Chhibber, S.; Patil, A.B.; Katare, O.P. Chitosan-Tailored Lipidic Nanoconstructs of Fusidic Acid as Promising Vehicle for Wound Infections: An Explorative Study. Int. J. Biol. Macromol. 2018, 115, 1012-1025. [CrossRef] [PubMed]

195. Dave, V.; Kushwaha, K.; Yadav, R.B.; Agrawal, U. Hybrid Nanoparticles for the Topical Delivery of Norfloxacin for the Effective Treatment of Bacterial Infection Produced after Burn. J. Microencapsul. 2017, 34, 351-365. [CrossRef] [PubMed] 
196. Verma, S.; Utreja, P. Vesicular Nanocarrier Based Treatment of Skin Fungal Infections: Potential and Emerging Trends in Nanoscale Pharmacotherapy. Asian J. Pharm. Sci. 2019, 14, 117-129. [CrossRef]

197. Dhiman, N.; Awasthi, R.; Sharma, B.; Kharkwal, H.; Kulkarni, G.T. Lipid Nanoparticles as Carriers for Bioactive Delivery. Front. Chem. 2021, 9, 580118. [CrossRef] [PubMed] 